\title{
UNIVERSAL SERVICE IN AN ALL-IP WORLD
}

\author{
Jodie Griffin
}

\section{INTRODUCTION}

Universality is the essential promise of the phone network. ${ }^{1}$ But today, as the phone network transitions to new technologies and as consumers increasingly rely on services like broadband access for business, education, civic engagement, and personal communications, many stakeholders have started to debate how exactly the nation will continue to fulfill its commitment to universal service as voice telephony and other communications services evolve. ${ }^{2}$

* Senior Staff Attorney, Public Knowledge.

1 See, e.g., Kevin D. Werbach, No Dialtone: The End of the Public Switched Telephone Network, 66 FED. CommC'NS L.J. 203, 208 (2014); see also H.R. Energy and Com. Comm., Universal Service Policy and the Role of the Federal Communications Commission 1 (2014), available http://energycommerce.house.gov/sites/republicans.energycommerce.house.gov/files/analys is/CommActUpdate/20140822White\%20Paper-USF.pdf ("The principle of universal service has long been at the heart of federal and state telephone policy.").

2 See, e.g., Office of Press Sec'y, Remarks by the President in the State of the Union Address, THE WHITE HOUSE (Jan. 20, 2015), http://www.whitehouse.gov/the-pressoffice/2015/01/20/remarks-president-state-union-address-january-20-2015 ("I intend to protect a free and open internet, extend its reach to every classroom, and every community, and help folks build the fastest networks, so that the next generation of digital innovators and entrepreneurs have the platform to keep reshaping our world."); see also Mignon Clyburn, Commissioner. Fed. Commc'ns Comm'n, Prepared Remarks at the American Enterprise Institute: Reforming Lifeline for the Broadband Era (Nov. 12, 2014), available at http://www.fcc.gov/document/commissioner-clyburn-remarks-american-enterprise-institute) ("As we discuss the prospect of reforming Lifeline, we are looking at allowing millions the opportunity to help themselves by connecting to jobs, employers, online education, and a host of services, which can dramatically improve and enrich their lives."); Tom Wheeler, Chairman, Fed. Commc'ns Comm'n, Prepared Remarks at 1776 Headquarters, The Facts and Future of Broadband Competition (Sept. 4, 2014), available at http://www.fcc.gov/document/chairman-remarks-facts-and-future-broadband-competition) ("Our universal service efforts are focused on bringing better broadband to rural America by whomever steps up to the challenge - not the highest speeds all at once, but steadily to prevent the creation of a new digital divide."). 
The public switched telephone network (PSTN) embodies the principle that everyone in the United States should have access to basic communications services. ${ }^{3}$ This principle of universal service is one of five fundamental values that guide our national communications policy, along with interconnection and competition, consumer protection, network reliability, and public safety. ${ }^{4}$

The structural protections built around our phone network impact everything from businesses' decisions about where to build new facilities to the personal communications we all conduct multiple times every day. ${ }^{5}$ For decades, people have assumed the network would always just work- because it did. ${ }^{6}$ This was not just a happy accident. Reliability requirements ensured phone lines would stay up during a power outage through backup power and generators that provided power through the copper line. ${ }^{7}$ Interconnection and nondiscrimination policies meant that any person with phone service could call any other person with a phone, regardless of which carriers the two subscribed to and where they each lived. ${ }^{8}$ Consumer protections prevented fraudulent charges or service changes and protected consumers' privacy on what is still one of the most trusted methods of communication today. ${ }^{9}$ And in the rare cases where any of these protections fail, we have government authorities that can step in quickly to restore service and provide redress to deter future problems. ${ }^{10}$

But especially in communications law, our concept of what constitutes "basic service" evolves as technology evolves. For example, in the Telecommunications Act of 1996, ${ }^{11}$ Congress expanded our conception of universal service to include advanced services as well as traditional phone services, and set in place certain policies aimed at giving everyone access to advanced services, like Internet access service, at just and reasonable rates. ${ }^{12}$ Today, one recent survey found that $89 \%$ of people think phone service is very or some-

\footnotetext{
3 See Jodie Griffin \& Harold Feld, PKthinks: Five Fundamentals for the Phone NETWORK TRANSITION 2 (2013), available at https://www.publicknowledge.org/files/PKThinks5Fundamentals.pdf; see also Wheeler, supra note 2.

4 GRIFFIN \& FELD, supra note 3.

$5 \quad I d$.

6 See id.

7 See id.

8 See id. at 7.

9 See Mary Madden, Public Perceptions of Privacy and Security in the Post-Snowden Era, Pew Research Center (Nov. 12, 2014), http://www.pewinternet.org/2014/11/12/publicprivacy-perceptions/.

10 GRIFFIN \& FELD, supra note 3; see, e.g., In the Matter of AT\&T Services Inc., Order File No. EB-TCD-14-00016243, Order (Apr. 8, 2015), available at https://apps.fcc.gov/edocs public/attachmatch/DA-15-399A1.pdf (settling a privacy violation by AT\&T with a $\$ 25$ million fine).

11 Telecommunications Act of 1996, Pub. L. No. 104-104, 110 Stat. 56 (1996).

12 Id. at 71-72.
} 
what important for the typical household, and $78 \%$ said the same for broadband service. ${ }^{13}$ This strongly indicates that, while universal voice service must remain a high priority, Internet access is increasingly seen as a necessity, not a luxury. ${ }^{14}$ As FCC Commissioner Mignon Clyburn has put it:

I have been in the regulatory space for over 16 years, and have never been more confident about any statement than the one I am about to make: Broadband is the greatest equalizer of our time. . . . In addition to the societal benefits, broadband has become is a necessity for an education, employment, improved healthcare, civic engagement and communication. ${ }^{15}$

As broadband access becomes increasingly popular and increasingly necessary for daily life, is voice service still the quintessential "basic service," or do we now include broadband service in the same category? Once we have decided what the "basic service" is, how do we know the extent to which we have achieved universal service? By what metrics do we measure interconnected voice or broadband service?

This paper will review the history of universal service values in the phone network, and will examine how those values were achieved through specific tools (including interconnection, cross-subsidies, and COLR obligations, among others). An understanding of how universal service was "operationalized" will help us understand how it can be achieved with the new networks and new technologies being tested and deployed today.

Universal basic service is a cornerstone of United States communications policy. ${ }^{16}$ It is essential for personal, business, and emergency communications for people across the country. ${ }^{17}$ But without fully understanding what our universal service goals are and how we will know whether we are achieving them, we will have no way to measure the efficacy of any regulatory or deregulatory regime. This paper therefore examines what "basic service" means today, for both voice and broadband, how we can measure that service, and how policymakers may achieve universal access and adoption.

13 John B. Horrigan, PhD, Consumers and the IP Transition: Communications PATtERN IN THE Midst OF TEChNOlOGicAl ChANGe 2 (2014), available at https://www.publicknowledge.org/assets/uploads/blog/Consumers.IP.Transition.FINAL.pdf.

14 See, e.g., Krishnadev Calamur, Broadband a 'Necessity,' Obama Says, As He Pushes FCC To Expand Access, NPR (Jan. 14, 2015, 2:16 PM), http://www.npr.org/blogs/thetwoway/2015/01/14/377230778/obama-pushes-fcc-to-expand-broadband-access (quoting President Barack Obama).

15 Clyburn, supra note 2 (emphasis in original).

16 See, e.g., Universal Service, FCC, http://www.fcc.gov/encyclopedia/universal-service (last visited Mar. 13, 2015).

17 GRIFFIN \& FELD, supra note 3, at 10. 


\section{UNIVERSAL SERVICE: ONE OF THE FUNDAMENTAL VALUES OF UNITED STATES COMMUNICATIONS POLICY}

United States national communications policy aims to ensure the benefits of communications technologies flow to everyone - regardless of race, color, religion, national origin, or sex. "We have, as a nation, decided to invest in a world-class communications infrastructure and so we should, as a nation, reap the benefits of that infrastructure." ${ }^{19}$ The principle of universal service applies whether users live in rural areas or urban areas. ${ }^{20}$ It applies to those with a physical disability that would interfere with communication. ${ }^{21}$ It applies to all users irrespective of their level of income. ${ }^{22}$ The efforts made pursuant to the goal of service to all Americans will include initiatives that go beyond traditional concepts of deployment and take advantage of the opportunities presented by new technologies. ${ }^{23}$

There is no reason that technology transitions should make the United States become the first industrialized nation to step back from the goal of making basic communications service available to $100 \%$ of its population. ${ }^{24}$ Even if the U.S. has not yet fulfilled its goal of universal affordable basic service, it is critical that our policies' goal continue to be $100 \%$ penetration, or the United States will let its own standards slide through mediocre goals and selfdefeatism.

This network transition is also an opportunity to look forward: what new opportunities are made possible by new technology, and how does that impact what we determine to be the "basic service" that all should have access to? Communications law specifies that universal service encompasses "an evolving level of telecommunications services" and that the FCC should take into account "advances in telecommunications and information technologies and services" as it decides what universal service will look like for homes, schools, libraries, and health care providers across the country. ${ }^{25}$ Access to basic communications services reaps tremendous social and economic benefits to users,

\footnotetext{
18 See 47 U.S.C. $\$ 151$ (2012); GRIFFIN \& FELD, supra note 3, at 6.

19 Griffin \& FELD, supra note 3, at 10; see, e.g., Andrew P. Morriss, Does the Internet Prove the Need for Government Investment?, FEE (Nov. 1, 1998), $\mathrm{http}: / /$ fee.org/freeman/detail/does-the-internet-prove-the-need-for-government-investment.

20 GRIFFIN \& FELD, supra note 3, at 10; see Telecommunications Act of 1996, Pub. L. No. 104-104, 110 Stat. 56, 71-72 (1996).

21 GRIFFIN \& FELD, supra note 3, at 10; 110 Stat. at 75.

22 GRIFFIN \& FELD, supra note 3, at 10; see 110 Stat. at 72.

23 GRIFFIN \& FELD, supra note 3, at 10; see 110 Stat. at 154.

24 GRIFFIN \& FELD, supra note 3, at 10.

2547 U.S.C. $\S 254$ (c) (2012).
} 
regardless of the material or technology used to transport the communications. ${ }^{26}$

This principle also entails a number of policies and rules designed to ensure the United States continues its goal of providing service to all Americans, including through carriers of last resort and rural build-out. Achieving service for all Americans also requires policies that ensure technology is deployed and is made truly accessible to traditionally marginalized communities in order to bring the social benefits of new technologies to those communities. This should include more than traditional anti-redlining rules.

Currently, the FCC's Connect2Compete program ${ }^{27}$ and merger conditions requiring Comcast to make affordable broadband available to low-income us$\mathrm{ers}^{28}$ are two examples of relatively recent efforts to promote adoption. While not perfect by any means ${ }^{29}$ these efforts do at least represent a recognition that the public interest for the $21^{\text {st }}$ Century goes beyond traditional concepts of deployment. ${ }^{30}$

It remains to be seen how the United States will continue to pursue the goal of $100 \%$ basic service for all Americans - regardless of location, income, or disability - as carriers stop maintaining their older, TDM-based facilities. ${ }^{31}$ Similarly, state carrier of last resort policies must be able to continue ensuring that all users are able to purchase reliable voice service under nondiscriminatory terms. ${ }^{32}$ These policies traditionally applied to all relevant carriers operating in some way on the traditional PSTN. ${ }^{33}$ Neither the make-up of the physical plant nor the protocols used to transport data on the network diminish consumers' need for basic service-if anything, advances and new efficiencies in

26 See, e.g., Eduardo Porter, Measuring the Benefits of Tech Tools, N.Y. TiMES, Apr. 30, 2013, at B1, B5.

27 See Tim Devaney, FCC Initiates Plan to Make Broadband Available to Low-Income Families, WASH. TIMES (Nov. 9, 2011), www.washingtontimes.com/news/2011/nov/9/fccinitiates-plan-to-make-broadband-available-to-/.

28 In the Matter of Applications of Comcast Corporation, General Electric Company and NBC Universal, Inc. for Consent to Assign Licenses and Transfer Control of Licensees, MB Docket No. 10-56, Memorandum Opinion and Order, 26 FCC Rcd 4238 para. 4 (Jan. 18, 2011).

29 See Amy Chozick, Mixed Response to Comcast in Expanding Net Access, N.Y. TIMES Jan. 20, 2013, at B1, B4.

30 See, e.g., Sam Gustin, Is Broadband Internet Access a Public Utility?, Time (Jan. 9, 2013), http://business.time.com/2013/01/09/is-broadband-internet-access-a-public-utility/.

31 See Sean Buckley, AT\&T, Verizon execs cite 'chilling' effect of murky TDM-to-IP transition regs, FIERCETELECOM (Oct. 9, 2013), http://www.fiercetelecom.com/story/attverizon-execs-cite-chilling-effect-murky-tdm-ip-transition-regs/2013-10-09 (stating that the FCC has set a 2017 goal for complete TDM shutdown and IP integration).

32 See, e.g., Cecilia Kang, Landline Rules Frustrate Telecoms, WASH. Post (Apr. 12, 2012), http://www.washingtonpost.com/business/economy/landline-rules-frustratetelecoms/2012/04/12/gIQAG2XvDT_story.html.

33 See id. 
technologies may justify raising the standard for what is considered basic service. $^{34}$

Of course, in achieving this goal the FCC's current refusal to classify VoIP service will eventually hit center stage. ${ }^{35}$ The FCC has in the past relied upon its ancillary authority under Title I of the Act to create universal service contribution obligations for interconnected VoIP providers, ${ }^{36}$ but has not made VoIP services eligible for funding for universal service. ${ }^{37}$ Although the FCC applied contribution obligations on interconnected VoIP providers for calls that did not actually touch the PSTN, it based its decision on the fact that interconnected VoIP services in general still offer the capability of reaching the PSTN.$^{38}$ This logic will become increasingly untenable as the PSTN moves to a system that looks more like interconnected VoIP than it does like the traditional PSTNunless the FCC updates its understanding of what constitutes the PSTN. ${ }^{39}$

"Similarly, in 2007 the [FCC] relied upon ancillary authority and its Title II jurisdiction ${ }^{40}$ to extend disability access requirements to interconnected VoIP providers and to manufacturers that design interconnected VoIP equip34 See id.
35 See generally Mike Masnick, VoIP Pioneer Worried About Net Neutrality Reclassifi-
cation-But Without It, Broadband Providers Could Kill VoIP Startups, TECHDIRT (Sept.
23, 2014, https://www.techdirt.com/blog/netneutrality/articles/20140922/16464528601/voip-pioneerworried-about-net-neutrality-reclassification-without-it-broadband-providers-could-killvoip-startups.shtml (describing, in other words, the central genesis of the Net Neutrality debate).

36 In the Matter of Universal Service Contribution Methodology; Federal-State Joint Board on Universal Service, 1998 Biennial Regulatory Review - Streamlined Contributor Reporting Requirements Associated with Administration of Telecommunications Relay Service, North American Numbering Plan, Local Number Portability, and Universal Service Support Mechanisms; Telecommunications Services for Individuals with Hearing and Speech Disabilities, and the American's with Disabilities Act of 1990; Administration of the North American Numbering Plan and North American Numbering Plan Cost Recovery Contribution Factor and Fund Size; Number Resource Optimization; Telephone Number Portability; Truth-in-Billing and Billing Format; and IP-Enabled Services, Report and Order and Notice of Proposed Rulemaking, WC Docket No. 06-122; CC Docket No. 96-45; CC Docket No. 98-171; CC Docket No. 90-571; CC Docket No. 92-237; NSD File No. L-00-72; CC Docket No. 99-200; CC Docket No. 95-116; CC Docket No. 98-170; WC Docket No. 0436, 21 FCC Rcd 7518, para. 16 (June 21, 2006), aff'd in relevant part sub nom., Vonage Holdings Corp. v. FCC, 489 F.3d 1232, 1236 (D.C. Cir. 2007) [hereinafter Universal Service Contribution Methodology Order] (creating universal service contribution requirements for interconnected VoIP providers).

37 Universal Service, FCC (Feb. 23, 2015), http://www.fcc.gov/encyclopedia/universalservice.

38 Universal Service Contribution Methodology Order, 21 FCC Rcd 7518, para. 36.

39 In this regard, nothing in the current regulatory definition of "public switched network" precludes the inclusion of VoIP services on the network. See 47 C.F.R. $§ 20.3$ (2012).

$40 \quad$ See 47 U.S.C. $\$ 225(b)(1)$ (2012). 
ment...." These requirements included "requiring interconnected VoIP providers to contribute to the Interstate Telecommunications Relay Services fund and to offer 7-1-1 abbreviated dialing for relay services." "B2 "But for these obligations to function, there must at some point be an actual Title II telecommunications service upon which to base ancillary authority. In considering this issue, the [FCC] must be mindful of the continued needs for disability access services and rules in the post-transition PSTN." ${ }^{43}$

One of the most important goals of communications policy in the United States is reaching universal service for all Americans across the country. The transition of the PSTN is an opportunity to expand and improve the communications service that all Americans receive, and the Commission must determine how it can continue to serve its statutory mandate as the traditional make-up of the PSTN changes. ${ }^{44}$

\section{UNIVERSAL SERVICE AND EVOLVING TECHNOLOGY}

As we look to what values should guide the transitions, we should carefully consider what values guided us on the old network. We should consider these not merely because they have shaped our national expectation on how our communications networks should work, but because of the incredible success of the network that was built on these principles.

For decades now, the PSTN's penetration rate into more than $90 \%$ of United States homes and businesses made it one of the national "systems of record" for enabling communications across the nation. ${ }^{45}$ Indeed, the new networks that have evolved, the Internet and the cell phone network, emerged out of the old communications network thanks to a series of policy decisions that made the

41 In re Technological Transition of the Nation's Communications Infrastructure, Comments of Public Knowledge, GN Docket No. 12-353, at 16 (Jan. 28, 2013) (accessible via FCC Electronic Comment Filing System) [hereinafter Comments of Public Knowledge]; see In the Matters of IP-Enabled Services; Implementation of Section 255 and 251(a)(2) of The Communications Act of 1934, as Enacted by The Telecommunications Act of 1996: Access to Telecommunications Service, Telecommunications Equipment and Customer Premises Equipment by Persons with Disabilities; Telecommunications Relay Services and Speech-toSpeech Services for Individuals with Hearing and Speech Disabilities; and The Use of N11 Codes and Other Abbreviated Dialing Arrangements, Report and Order, WC Docket No. 04-36, WT Docket No. 96-198, CG Docket No. 03-123, CC Docket No. 92-105, 22 FCC Rcd. 11275, para. 1 (May 31, 2007).

42 Comments of Public Knowledge, GN Docket No. 12-353, at 17; see IP-Enabled Services, 22 FCC Rcd. 11275, paras. 36, 42.

43 Comments of Public Knowledge, GN Docket No. 12-353, at 16-17.

44 Id. at 17; see, e.g., William Kennard, Chairman, Fed. Commc'ns Comm'n, Chairman Kennard's Agenda for the FCC for 1999, FCC, http://transition.fcc.gov/Speeches/Kennard/Statements/stwek901.html (last visited Mar. 14, 2015).

45 Technical Advisory Council, Critical Legacy Transitions Working Grp., Fed. COMMC'NS COMM'N, Sun-SETTING THE PSTN 20 (2011). 
ubiquitous traditional telephone network an open and reliable platform for everyone to use. ${ }^{46}$

In addition, policies like universal service have created a positive feedback loop by maintaining the central position of the PSTN to the communications infrastructure and reinforcing the importance and universality of the PSTN. ${ }^{47}$ This history has built a series of networks that lie at the heart of the United States' economy and culture..$^{48}$ An examination of what policies created such success in the traditional phone network will help inform what policies we need to implement as the network transitions to its next iteration.

\section{THE HISTORY OF UNIVERSAL SERVICE}

Many trace the first prominent use of the term "universal service" in the United States back to a 1908 AT\&T advertisement, ${ }^{49}$ but the concept of universal communications service appeared much earlier than that, from the construction of postal roads that pre-date the United States Constitution ${ }^{50}$ to proposals for the Uniform Penny Post in the United Kingdom in the 1830s. ${ }^{51}$

In the beginning of the $20^{\text {th }}$ Century, policymakers had to confront a series of policy questions that would shape the development of our national communications infrastructure for decades to come. ${ }^{52}$ AT\&T had built out its network, but had also attained dominance in both local and long-distance telephone services. ${ }^{53}$ However, competing carriers found it difficult to offer customers competing voice services that let them connect with anyone else with a phone, be-

46 Jason Oxman, Counsel for Advanced Commc'n, The FCC and the Unregulation of the Internet 3, 15-16 (Fed. Commc'ns Comm'n, Office of Plans and Policy, Working Paper No. 31, July 1999); see H.R. REP. No. 103-213, at 492-93 (1993) (Conf. Rep.), reprinted in 1993 U.S.C.C.A.N. 1088, 1181-82.

47 See Oxman, supra note 46, at 6 (stating that the Commission maintained universal access to the telecommunications network which the Internet relies on to operate, while simultaneously ensuring the unregulated development of the Internet).

48 See id. at 15.

49 Milestones in HT\&T History, AT\&T, http://www.thocp.net/companies/att/att_company.htm (last Mar. 13, 2015). At the time, the use of "universal" service was intended to counter the concept of introducing competition in the marketplace, but the company's arguments were nevertheless based on the observation: "[t]hat the American public requires a telephone service that is universal is becoming plainer every day." See AT\&T, One Policy, One System, Universal Service, BroOKLYN LIFE, Nov. 28, 1908, at 25, available at http://bklyn.newspapers.com/image/83167928/.

50 Colonial Times, U.S. POSTAL SERvice, https://about.usps.com/publications/pub100/pub100_002.htm (last visited Mar. 13, 2015).

51 See J. C. Hemmeon, The History of The British Post Office 60 (1912).

52 See, e.g., GRIFFIN \& FELD, supra note 3, at 2, 5-6.

53 See Milton Mueller, Universal Service: Competition, Interconnection And Monopoly in the MAKIng OF THE AMERICAN Telephone System 91 (1997), available at http://surface.syr.edu/cgi/viewcontent.cgi?article=1017\& context=books. 
cause AT\&T employed the strategy of refusing to let independent local network interconnect with AT\&T's long-distance network. ${ }^{54}$ Without being able to complete calls to AT\&T's customers, independent carriers were at a disadvantage, towns where AT\&T had not deployed its network were left without a bridge to the rest of the world, and AT\&T gained a monopolistic position in the market. ${ }^{55}$

This pattern culminated in a 1913 antitrust lawsuit filed by the United States against AT\&T. ${ }^{56}$ Perhaps guided by Congress' simultaneous consideration of nationalizing the long-distance telephone network, AT\&T decided to settle the lawsuit with an agreement known as the Kingsbury Commitment. ${ }^{57}$ As part of that settlement, AT\&T agreed to let independent local telephone carriers interconnect with AT\&T's long-distance network, in addition to divesting Western Union and not purchasing other companies against the objections of the Interstate Commerce Commission. ${ }^{58}$

The Kingsbury Commitment was by no means a comprehensive universal service policy, but it did use interconnection as a key tool in enabling competition and network build-out. ${ }^{59}$ AT\&T could still impose an access charge on independent carriers, and AT\&T would not interconnect its local exchange with independent carriers' local exchanges, but the agreement was nonetheless a historic step forward in developing national communications policy ${ }^{60}$ Subsequently, federal law would recognize the importance of interconnection by broadly requiring telecommunications carriers to interconnect with one anoth$\mathrm{er},{ }^{61}$ and even towards the end of the $20^{\text {th }}$ Century, Congress went further in detailing the interconnection requirements of telecommunications carriers and incumbent local exchange carriers (ILECs) in particular. ${ }^{62}$

Thus, universal service, along with other key fundamental values, shaped the development of communications policy in the United States, from basic interconnection commitments under antitrust law to policies that now include interconnection, intercarrier compensation, carrier of last resort (COLR) rules, and universal service support programs, to name just a few. Together, these policies have created a national telecommunications infrastructure that became

\footnotetext{
54 See id. at $75,102$.

55 See id. at 91.

56 See id. at 127.

57 Letter from Nathan Kingsbury, AT\&T Vice President to the Attorney General (Dec. 19, 1913), in AT\&T Co., 1913 ANNUAL REPORT 24, 24 (1914).

$58 \quad I d$. at $24,26$.

59 See GRIFFIN \& FELD, supra note 3, at 5-6.

60 See MuELlER, supra note 53, at 128.

61 See Communications Act of 1934, Pub. L. No. 416, § 201(a) (1934).

62 See Telecommunications Act of 1996, Pub. L. No. 104-104, § 101(a), 110 Stat. 56 (codified at 47 U.S.C. $\S 251(a)$ ).
} 
the envy of the world..$^{63}$ And now, as the network continues to develop, smart policymaking will continue to seize opportunities to expand and improve service without leaving anyone behind.

\section{THE FIRST MAJOR TRANSITION: FROM NATURAL MONOPOLY TO COMPETITION}

Even after the Kingsbury Commitment opened the market to independent network build-out and competition, Congress continued to develop rules to protect the people relying on the network and encourage a robust marketplace. ${ }^{64}$ As the telecommunications marketplace evolved to include competing carriers, policymakers used that developing competition to encourage build-out to underserved areas while also placing competitive pressure on incumbents in areas that already had service.

In the early years of our telecommunications networks, we served core network values like reliability and universal service through a "natural monopoly" system. ${ }^{65}$ Each local area was served by a telecommunications carrier with a local monopoly - often through AT\&T or "Ma Bell." cross-subsidized local service through long-distance charges and sometimes through a regulated rate-of-return. ${ }^{67}$

As technology has developed since the Kingsbury Commitment and the Communications Act of 1934, policymakers have shifted from policies designed to support and seek benefits from a monopoly-based system to one that promotes the benefits of competition wherever possible, complemented with policies that ensure we achieve basic values like universal service even where competition fails.$^{68}$ After some time in the AT\&T monopoly, companies like MCI were able to enter the long-distance market to offer better rates and innovative new services for users ${ }^{69}$ Later on, wireless carriers were able to use cellular technologies to offer consumers mobility in basic voice service and com-

\footnotetext{
63 Kennard, supra note 44.

64 Bob Adelmann, The Breakup of Ma Bell, ThE New AM. (May 12, 2010), http://www.thenewamerican.com/economy/sectors/item/4297-the-breakup-of-ma-bell.

65 A "natural monopoly" is defined as a service best delivered by one company rather than two or more competitors. Universal Service, supra note 16.

66 Id.

67 Claude Fischer, America Calling: A Social History of the Telephone to 1940 369 (U. of Cal. Press 1994), available at http://quod.lib.umich.edu/cgi/t/text/text$\mathrm{idx} ? \mathrm{c}=\mathrm{acls} ; \mathrm{cc}=\mathrm{acls} ; \mathrm{view}=$ toc;idno $=$ heb00141.0001.001.

68 See GRIFFIN \& FELD, supra note 3, at 6.

69 See Regulatory Reform: A Survey of the Impact of Reregulation and Deregulation on Selected Industries and Sectors, 47 ADMIN. L. REV. 569, 574 (1995) (stating that despite its prior existence, MCI was able to compete more efficiently in the long distance market in the wake of the Modern Final Judgment which divested the Baby Bells).
} 
pete - albeit imperfectly—with traditional local phone service. ${ }^{70}$ Later, a series of policy actions including the break-up of the AT\&T and Bell monopoly in 1984 , and the introduction of the spectrum auction in $1993^{71}$ confirmed competition as a fundamental principle in the nation's communications industry. ${ }^{72}$

But throughout this paradigm shift from monopoly to competition, policymakers ensured that changes in the network did not undermine the other core network values: universal service, consumer protection, reliability, and public safety. ${ }^{73}$ For universal service, this also involved the implementation of new policies and programs, like the Universal Service Fund, programs to bring service to rural areas, low-income communities, and anchor institutions. ${ }^{74}$ In other cases, old tools found new uses. The interconnection rules that had initially served as universal service tools to help independent carriers and towns connect to the national network have since proved to be among the most important competition tools used by policymakers today. ${ }^{75}$ With carriers required to allow users to connect any non-harmful devices of their choosing to the network, consumers had access to competitive choice in telephone equipment in addition to new technologies like fax machines and answering machines. ${ }^{76}$ Similarly, rules that allowed "electronic publishers" and other "enhanced service providers" to interconnect with the telephone network set the stage for a new universe of services that rode on top of the phone network, like security systems, medical alerts, and voicemail. ${ }^{77}$ And of course, these rules ultimately led to the creation of the dial-up modem-running on the traditional phone networkand some of the earliest work on the Internet. ${ }^{78}$ All of these developments were

70 See id. at 576 ("In business and residential markets, the Bells are also facing increased competition from cellular carriers.”).

71 See Omnibus Budget Reconciliation Act of 1993, Pub. L. 103-66, § 6001, 107 Stat. 312, 379 (1993).

72 See, e.g., Regulatory Reform, supra note 69, at 571.

73 See In the Matters of IP-Enabled Services and E911 Requirements for IP-Enabled Service Providers, First Report and Order and Notice of Proposed Rulemaking, WC Docket No. 04-36, WC Docket No. 05-196, 20 FCC Rcd 10245 (May 19, 2005) [hereinafter IPEnabled E-911 Requirements Order].

74 Telecommunications Act of 1996, Pub. L. No. 104-104, § 254, 110 Stat. 56, 72 (1996).

75 U.S. v. Am. Tel. \& Tel. Co., 524 F.Supp. 1336 (D.D.C. 1981); see Steven Semeraro, The Antitrust-Telecom Connection, 40 SAn DiEgo L. Rev. 555 (2003) ("The Act is legislative competition policy-making that stimulates rivalry in local telephone service principally by requiring 'incumbent local exchange carriers' (ILECs), the existing local telephone companies, to interconnect with, and provide certain services.").

76 See Nicholas Johnson, Carterfone: My Story, 25 SANTA Clara Computer \& High TECH. L.J. 677, 677 (2008) (discussing the extent of innovation in the wake of the FCC's Carterfone decision).

77 See $§ 274,110$ Stat. at 102.

78 Philip J. Weiser, Regulating Interoperability: Lessons From AT\&T, Microsoft, and Beyond, 76 ANTITRUST L.J. 271 (2009-2010). 
made possible by a suite of policies designed to ensure ubiquitous and affordable access to an open, neutral communications network.

\section{POLICIES FOR NEWER NETWORKS: VOICE-OVER-IP, CABLE AND WIRELESS RISE AND THRIVE WITH THE "COPPER SAFETY NET"}

Policymakers' efforts to achieve ubiquitous, affordable services have not been without their share of twists and bumps in the road. As new voice services entered the market,$^{79}$ federal and state policymakers alike have faced the questions of whether and how to implement the fundamental values of the network to new technologies. ${ }^{80}$

For decades, the FCC avoided many of these hard questions, instead using ad hoc decisions to create a patchwork of policies with no real guiding framework or consistent principles. ${ }^{81}$ Unsurprisingly, the result has been an inconsistent hodge-podge that risks segregating the most powerful and critical policies to traditional voice service offered over the "copper safety net." ${ }^{92}$ Even now that the FCC has reclassified broadband Internet access service as a Title II telecommunications service, ${ }^{83}$ there remain many questions, both about the classification of services like interconnected VoIP and text messaging services and about exactly how the core network values should be applied to each of these services.

For voice service in particular, the effectively unclassified status of interconnected VoIP continues to cast uncertainty over the policy discussions about the future of the voice network. In 2004, Vonage asked the FCC to classify interconnected VoIP as a Title I information service, and thereby pre-empt the Minnesota Public Utilities Commission ("PUC") from applying telephone service rules to Vonage's interconnected VoIP service. ${ }^{84}$ The FCC did preempt the Minnesota PUC's order, but it did not classify interconnected VoIP as either a telecommunications service or an information service. ${ }^{85}$ However, in a separate

79 See Werbach, supra note 1, at 275 (explaining that customers are switching from incumbent wireline providers to wireless phones and VoIP).

80 See, e.g., GRIFFIN \& FELD, supra note 3, at 7.

81 See In the Matter of IP-Enabled Services, Notice of Proposed Rulemaking, WC Docket No. 04-36, 19 FCC Rcd 4863 at para. 46 (Feb. 12, 2004).

82 GRIFFIN \& FELD, supra note 3 at 7; see IP-Enabled Services NPRM, 19 FCC Rcd 4863 at para. 46 .

83 See generally Protecting and Promoting an Open Internet, GN Docket No. 14-28, Report and Order on Remand, Declaratory Ruling, and Order (Feb. 26, 2015).

84 In the Matter of Vonage Holdings Corporation Petition for Declaratory Ruling Concerning an Order of the Minnesota Public Utilities Commission, Petition for Declaratory Ruling, WC 03-211 (Sept. 22, 2003).

85 See In the Matter of Vonage Holdings Corporation Petition for Declaratory Ruling Concerning an Order of the Minnesota Public Utilities Commission, Memorandum Opinion and Order, WC Docket No. 03-211, 19 FCC Red 22404 at para. 1 (Nov. 9, 2004). 
proceeding, the FCC also affirmed that AT\&T's traditional copper-based network would still be treated as a traditional phone service in some ways even when it used IP in the middle of the network. ${ }^{86}$ But on the whole, interconnected or non-nomadic VoIP still remains largely unclassified for regulatory purposes. $^{87}$

The FCC, however, has applied some rules to interconnected VoIP providers in various proceedings, using the Commission's ancillary authority or authority under section $706 .^{88}$ Neither of these sources of authority, however, provide the same level of certainty that Title II would offer. Ancillary authority must, after all, be ancillary to something, and it is not clear how a theory of ancillary authority could stand in a world where the network has been entirely transitioned to new technologies. ${ }^{89}$ And section 706 , while providing strong authority for the Commission in some respects, is limited by the "common carrier prohibition"-in other words, the Commission may only treat a provider as a common carrier if it classifies that provider as a telecommunications carrier..$^{90}$ Therefore, while these obstacles are not a problem for services that are already classified as Title II telecommunications services, like traditional POTS service and broadband Internet access service, the FCC's legal authority will continue to

86 In the Matter of Petition for Declaratory Ruling that AT\&T's Phone-to-Phone IP Telephony Services are Exempt from Access Charges, Order, WC Docket No. 02-361, 19 FCC Rcd 7457 at para. 1 (Apr. 14, 2004).

87 See Vonage Holdings, 19 FCC Rcd 22404 at para. 32.

88 See Universal Service Contribution Methodology Order, 21 FCC Rcd 7518, para. 35 (creating universal service contribution requirements for interconnected VoIP providers under section 254(d)); IP-Enabled E-911 Requirements Order, 20 FCC Rcd 10245, 7 at para. 27 (extending disabilities access requirements to interconnected VoIP under ancillary authority); In the Matter of Telephone Number Requirements for IP-Enabled Services Providers, Local Number Portability Porting Interval and Validation Requirements, IP-Enabled Services, Telephone Number Portability, CTIA Petitions for Declaratory Ruling on Wireline-Wireless Porting Issues, Final Regulatory Flexibility Analysis, Numbering Resource Optimization, Report and Order, Declaratory Ruling, Order on Remand, and Notice of Proposed Rulemaking, WC Docket No. 07-243, WC Docket No. 07-244, WC Docket No. 0436, CC Docket No. 95-116, CC Docket No. 99-200, 22 FCC Rcd 19531, para. 17 (Oct. 31, 2007) [hereinafter Local Number Portability Declaratory Ruling] (extending local number portability requirements to interconnected VoIP providers under ancillary authority); In the Matter of Implementation of the Telecommunications Act of 1996, Telecommunications Carriers' Use of Customer Proprietary Network Information and Other Customer Information, IP-Enabled Services, Report and Order and Further Notice of Proposed Rulemaking, 22 FCC Rcd 6927, para. 54 (2007); Id. at n.3 (extending CPNI rules to interconnected VoIP service under ancillary authority).

89 See Local Number Portability Declaratory Ruling, 22 FCC Rcd 19531, para. 28 (Oct. 31,2007 ) (noting the Commission has ancillary authority because interconnected VoIP service is rapidly overtaking traditional telephone service).

90 See 47 U.S.C. $§ 153(51)$ (2012); see Verizon v. FCC, 740 F.3d 623, 651 (D.C. Cir. 2014). 
be a practical barrier to implementing a consistent policy framework on services that have not been classified.

\section{WHAT IS THE BASIC SERVICE?}

Before anyone can study or choose amongst the different approaches for achieving universal service, we have to first determine what the universal "basic service" is. Although basic voice service is still near-universally subscribed to and relied upon for many users' most important communications, ${ }^{91}$ there is emerging agreement around the notion that broadband access should also be considered a "basic service" that is similarly necessary for personal, business, and emergency communications. ${ }^{92}$

\section{INTERCONNECTED VOICE SERVICE}

Even as new technologies develop and attract more users, voice service, as coordinated by the North American Numbering Plan, continues to be a basic service for networks users across the country. ${ }^{93}$ Whether looking at the activities voice service supports or rates of adoption among users, it is clear that almost everyone in the country relies on voice service for critical functions. ${ }^{94}$

Basic voice service remains an important foundation of communications in the United States. People still need voice service to contact $911,{ }^{95}$ call their loved ones, and conduct business. ${ }^{96}$ Even as new technologies arise, basic interconnected voice service continues to be the backstop that people across the country rely on. ${ }^{97}$ Online e-mail forms and chat forums for customer service have become very popular, but when customers want to talk directly to another person, they turn to the company's phone line. ${ }^{98}$ Similarly, text messaging has

91 See In the Matter of IP-Enabled Services, Notice of Proposed Rulemaking, WC Docket No. 04-36, 19 FCC Rcd 4863, para. 5 (Feb. 12, 2004) [IP-Enabled Services NPRM].

92 Id. at para. 8.

93 Werbach, supra note 1, at 207.

94 In the Matter of IP-Enabled Services NPRM, 19 FCC Rcd 4863, para. 18.

95 The FCC has encouraged voluntary commitments and recently announced new rules for implementing text-to-911 service, but for multiple reasons voice calls are still the nearonly way customers contact emergency services. In the Matter of Facilitating the Deployment of Text-to-911 and Other Next Generation 911 Applications, Framework for Next Generation 911 Deployment, Second Report and Order and Third Further Notice of Proposed Rulemaking, PS Docket No. 11-153, PS Docket No. 10-255, 29 FCC Rcd 9846, para. 10 (Aug. 13, 2014) [Facilitating Text-to-911 Order].

96 IP-Enabled Services NPRM, 19 FCC Rcd 4863, para. 19.

97 Id. at para. 10.

98 See Jordan Minor, How to Talk to a Live Person: Every Customer Support Number

You'll Ever Need, PC MAG. (Dec.


been a tremendously popular tool for casual conversation, ${ }^{99}$ but when Mother's Day comes around, everybody still picks up the phone.

Access to basic phone service is also presupposed throughout federal law and regulation..$^{100}$ Many of the federal and state governments' social support programs depend on phone access to disburse information and collect complaints. ${ }^{101}$ In all of the following ways, the functioning of many nontelecommunications laws and policies depends on universal and reliable access to communications networks:

\section{Role of Communications Service Statute}

States agencies are required by law to maintain tollfree numbers for non-English speaking persons to access more information about food stamps. Anyone seeking to 7 U.S.C. $\$ 2020(\mathrm{e})(2)(\mathrm{C}) ; 7$ C.F.R. $\S 272.4(b)(3) ; 7$ C.F.R. $\S$ file a discrimination complaint regarding the Supplemental Nutrition Assistance Program will also need to provide the Food and Nutrition Service with a contact phone number. Federal law also gives states the option of allowing applicants to sign their applications via recorded verbal assent over the phone.

The law requires the National Emergency Child Loca6 U.S.C. $\S 774(b)(3)(A)$. tor Center to maintain a toll-free phone number to receive reports about displaced children.

The Secretary of Defense must maintain a national tel10 U.S.C. $§ 1794(b)(1)$. ephone number to receive reports of suspected child abuse or safety violations at a military child development center or day care.

http://www.pcmag.com/article2/0,2817,2427973,00.asp (providing the direct customer service phone numbers for several major retailers as an alternative to online access methods).

99 Facilitating Text-to-911 Order, 29 FCC Rcd 9846, para. 3.

100 See Lifeline Program for Low-Income Consumers, FCC, http://www.fcc.gov/lifeline (last visited Mar. 13, 2015) (providing that a federal program has been in existence since 1985 that assists low-income individuals to gain access to cellular telephones, further implying that the government presumes that individuals have access to telephones).

101 Soc. Sec. Admin., Disability Benefits 2 (2014) (demonstrating that, for example, the Social Security Administration provides a telephone number to discuss disability benefits). 
Federal law requires the secretary of Housing and Ur-

12 U.S.C. $\S 1701 x(c)(5)(D)(i)$ ban Development to maintain a telephone hotline for homeowners to obtain information about homeownership counseling.

Servicers of federally related mortgages must maintain 12 U.S.C. § 2605(b)(3). toll-free phone numbers to answer inquiries about servicing transfers.

State and local governments' multidisciplinary child 18 U.S.C. $\S 3509(\mathrm{~g})(2)(\mathrm{B})$. abuse teams offer services including telephone consultations in emergencies and other situations.

The Secretary of Education must maintain a toll-free 20 U.S.C. $\S 1090(c)$. phone service to handle questions about financial aid applications.

The National Center for School and Youth Safety 20 U.S.C. $§ 7138(b)(2)$. maintains a toll-free phone line for students to anonymously report criminal activity and other high-risk behaviors.

Federal law gives retailers the right to request a hearing 21 U.S.C. $\S 333(f)(8)$. by phone before the Food and Drug Administration for violations of tobacco sale laws.

The Secretary of State must maintain a toll-free phone 22 U.S.C. $\S 5504(b)$. number for families of citizens involved in disasters abroad.

Federal law instructs the Department of Health and 42 U.S.C. § $280 \mathrm{i}-1(\mathrm{c})(2)(\mathrm{C}) ; 42$ Human Services (HHS) to use toll-free phone lines to make information available about autism spectrum disorder, Alzheimer's Disease, and AIDS.

U.S.C. $\S \S 285 \mathrm{e}-7(\mathrm{~b}), 285 \mathrm{e}-8(\mathrm{~b})(2)$; 42 U.S.C. $\S \S 300 \mathrm{cc}-17(\mathrm{~b}), 300 \mathrm{ee}-$ 31(c).

The Substance Abuse and Mental Health Services Ad42 U.S.C. $\S 290 \mathrm{bb}-34(\mathrm{c})(3)$. ministration must require grant recipients providing research, training, and technical assistance to maintain tollfree informational phone lines. 


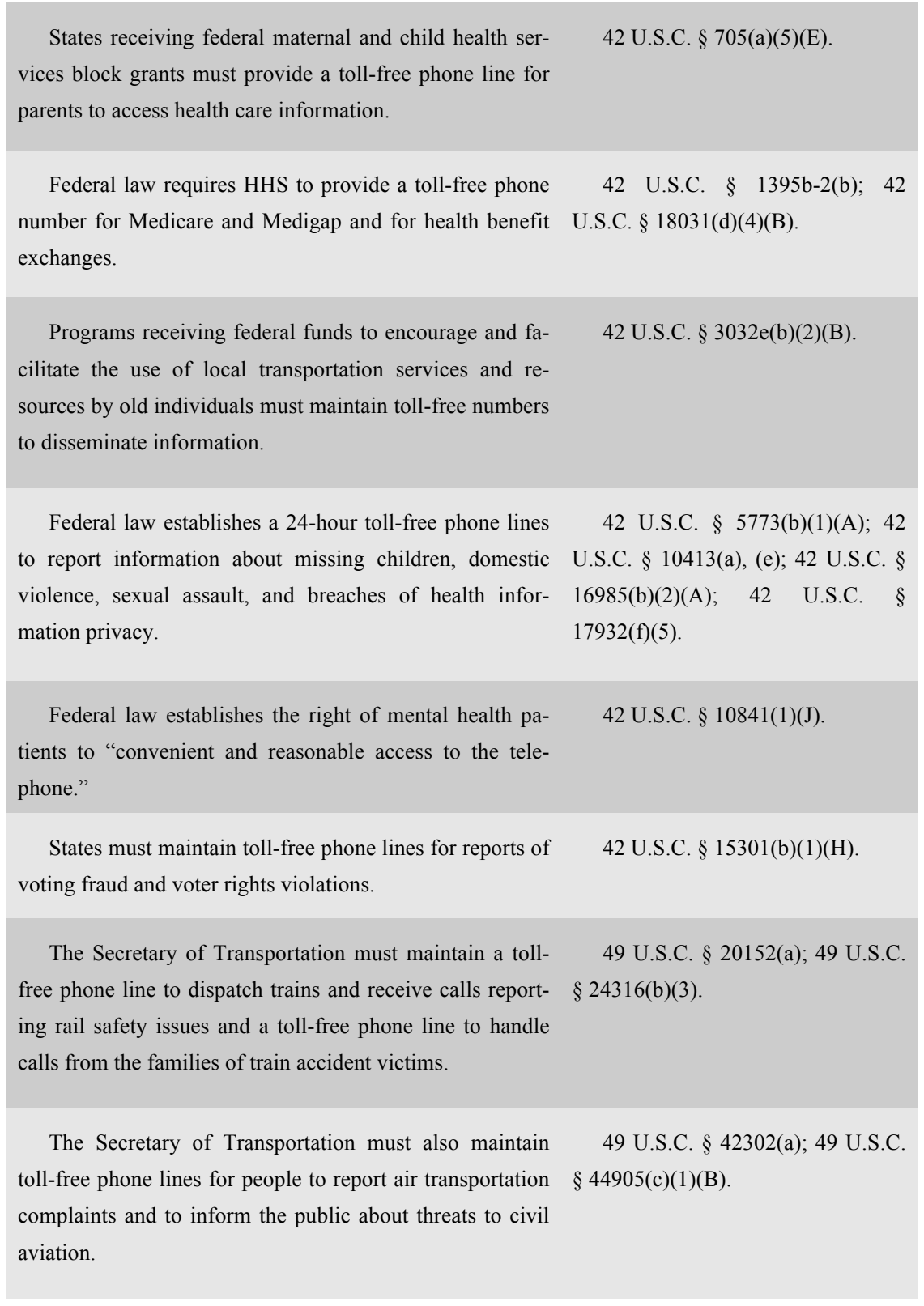

Even beyond the types of uses made by the public using basic voice service, interconnected voice service remains a basic service by virtue of the sheer number of people who continue to rely on it. ${ }^{102}$ By June 2013, there were 441

102 See Fed. Commc'ns Comm'n, Indus. Analysis and Tech. Division: Wireline 
million retail phone service connections in the United States, of which 90 million were end-user switched access lines and 45 million were interconnected VoIP lines. ${ }^{103}$ Even only looking at residential wireline phone service, the United States still has one such active line for every four people in the country. ${ }^{104} \mathrm{In}$ addition, the Federal Communications Commission continues to require all Universal Service Fund recipients to offer basic voice service..$^{105}$

Basic voice service can to some extent be delivered using various technologies and infrastructure, but new technologies may vary in some aspects from the traditional TDM-based voice service delivered over copper infrastructure. ${ }^{106}$ In terms of consumer perception, it is unclear whether users who switch from traditional TDM-based copper phone service to a wireline interconnected VoIP service are made fully aware of all of the differences between copper, cable, and fiber infrastructure. ${ }^{107}$ For example, one of the most prominent distinguishing characteristics of copper-based service is copper's ability to receive power through the line - an especially useful feature during commercial power outages. ${ }^{108}$ However, after some recent outages, reports surfaced of customers remarking on how they were surprised by the fact that their cable or fiber service

Competition Bureau, Internet Access Services: Status As of June 30, 20131 (2014) (demonstrating the number of people who rely on these services).

$103 \mathrm{Id}$. at 1.

104 See id. at 2-3. The United States' population as of June 30, 2013, is estimated at 316,122,143. U.S. World and Population Clock, U.S. Census BurEau, http://www.census.gov/popclock/_(last visited Mar. 13, 2015) (follow "Select a Date" hyperlink; then choose "June 30, 2013").

105 In the Matter of Connect America Fund, A National Broadband Plan for Our Future, Establishing Just and Reasonable Rates for Local Exchange Carriers, High-Cost Universal Service Support, Developing an Unified Intercarrier Compensation Regime, Federal-State Joint Board on Universal Service, Lifeline and Link-Up, Universal Service Reform - Mobility Fund, Report and Order and Further Notice of Proposed Rulemaking, WC Docket No. 10-90, GN Docket No. 09-51, WC Docket No. 07-135, WC Docket No. 05-337, CC Docket No. 01-92, CC Docket No. 96-45, WC Docket No. 03-109, WT Docket No. 10-208, 26 FCC Rcd 17663 paras. 77,78, 84 (Oct. 27, 2011) (describing the core functionalities of supported services as "voice telephone service," in order to focus on the functionality offered rather than the technology used).

106 In the Matter of Ensuring Customer Premises Equipment Backup Power for Continuity of Communications, Technology Transitions, Policies and Rules Governing Retirement Of Copper Loops by Incumbent Local Exchange Carriers, Special Access for Price Cap Local Exchange Carriers, AT\&T Corporation Petitions for Rulemaking to Reform Regulation of Incumbent Local Exchange Carrier Rates for Interstate Special Access Services, Notice of Proposed Rulemaking and Declaratory Ruling, PS Docket No. 14-174, GN Docket No. $13-$ 5, RM-11358, WC Docket No. 05-25, RM-10593, 29 FCC Rcd 14968 para. 1 (Nov. 21, 2014).

107 See id. at paras. 94, 112 (explaining that the FCC is still grappling with whether or not this information should be available to consumers).

108 Mitch Lipka, Phone Carriers Migrating From Copper to Fiber Optic Lines, Bos. GlOBE (Aug. 31, 2014), http://www.bostonglobe.com/business/2014/08/30/copper-fiberphone-service-better-fight-than-switch/83SzuNwB4QmJbyM1Rfmg1J/story.html. 
was not also self-powered and went down during the power outage, leaving them unable to make emergency calls. ${ }^{109}$

In contrast, many of the customers who have chosen to continue to use copper-based phone service - either instead of or in addition to a wireless phoneseem very cognizant of the benefits of traditional copper service. ${ }^{110}$ One recent survey found that nearly half of respondents had both wireline and wireless phone service. ${ }^{111}$ Of those consumers, $65 \%$ reported that they mostly use their landline phone to make calls when they are home. ${ }^{112}$ Among those with household incomes under $\$ 25,000,72 \%$ of respondents with both landline and mobile phones mostly use their landline phone when at home. ${ }^{113}$ Among respondents with both landline and mobile phones, $82 \%$ of respondents reported that they keep their landline because of its reliability, 73\% appreciated the connection quality of the landline as compared to the wireless phone, and $45 \%$ kept a landline because it would stay up during an electrical outage. ${ }^{114}$

Additionally, in several areas across the country, many of those customers have spoken out when they felt their phone company was not adequately maintaining the copper line ${ }^{115}$ or was trying to force customers onto a new service. ${ }^{116}$ These customer complaints also have the effect of complicating any cause-andeffect analysis of the reported movement from copper and switched access lines to interconnect VoIP or other infrastructure ${ }^{117}$ If it is the case that at least some carriers are failing to maintain their copper service or carriers' customer service representatives incorrectly telling customers they must switch to new

109 Surprise! Your high-tech home phone system could go dead in an emergency, CoNSUMERREPORTS.ORG (Jan. 2012), http://www.consumerreports.org/cro/2012/01/surpriseyour-high-tech-home-phone-system-could-go-dead-in-an-emergency/index.htm\#.

110 The most recent survey results indicate approximately 83 million of the 90 million active switched access lines still use copper local loops to deliver service. FED. COMMC'NS COMM'N, supra note 102, at 9.

111 HORRIGAN, supra note 13.

112 Id.

$113 I d$.

114 Id. On the point of self-powered phone service, landline phone service offered over cable or wireline VoIP technologies would not be powered through the line that way traditional copper-based phone service is. As a result, some landline phone customers may not report preferring their landline because it is self-powered because their particular line is not, in fact, self-powered.

115 Letter from Jodie Griffin, Senior Staff Attorney, Public Knowledge, to Julie A. Veach, Chief, Wireline Competition Bureau, Fed. Commc'ns Comm'n (May 12, 2014), available

https://www.publicknowledge.org/assets/uploads/blog/14.05.12_Copper_Letter.pdf.

116 Id.; Pub. Knowledge, The Phone Network Transition: Lessons from Fire IsLAND $\quad 1 \quad$ (2014) available at https://www.publicknowledge.org/assets/uploads/documents/Lessons_from_Fire_Island_On e-Pager.pdf.

117 See Fed. COMMC'NS COMM'N, supra note 102, at 14. 
technologies, it becomes much more difficult to discern whether customer migrations occur because customers freely choose a different technology over a properly-maintained basic voice service, or because carriers' failure to fulfill their legal obligations as telecommunications services make newer technologies more attractive in comparison. ${ }^{118}$ Parsing the causes and effects in this area will likely continue to be difficult, if not impossible, until relevant state and federal authorities have at least investigated pending complaints. ${ }^{119}$

\section{BROADBAND ACCESS SERVICE}

The idea that broadband access service itself has now become a "basic service," that is properly included in universal service policies, is gaining increasing traction among many stakeholders. ${ }^{120}$ Broadband is only becoming more and more necessary for day-to-day personal, educational, and occupational activities. ${ }^{121}$ Additionally, some of the government's existing policies promoting universal communications service have already been updated to include broadband access. ${ }^{122}$ For example, the FCC's recent update of its Universal Service Fund disbursements requires eligible telecommunications carriers (ETCs) to offer broadband in their supported service areas. ${ }^{123}$

Broadband is increasingly necessary for personal communications, economic advancement, and civic engagement for people across cultural and socioeconomic divides. ${ }^{124}$ Certain VoIP and video chat services use broadband connections to help people communicate with loved ones, which is especially useful

118 See Letter from Jodie Griffin, supra note 115 (demonstrating that many companies have been permitting their copper wires to fall in disrepair in order to force transfer to different technologies); see also PUB. KNOWLEDGE, supra note 116 (further demonstrating that individuals are being forced to transfer to different technologies whether or not that is their desire).

119 See Pub. Knowledge, supra note 116, at 6 (demonstrating the importance of the relationship between consumers and state and federal governments).

120 See FED. COMMC'NS COMM'N, supra note 102 (explaining that VoIP requires broadband service and that the FCC started requiring reports on this system in December 2008).

121 James Vollman \& Anthony CARnevale, National BroAdBand Plan BRoAdBAND ACCESS FOR All Americans FaCilitating an EFFicient and EFFECTIVE Labor MARKET (2009), available at https://cew.georgetown.edu/wp-content/uploads/2009/12/0951-12-04-2009-Anthony-P.-Carnevale-7020351160.pdf.

122 USF/ICC Transformation Order, 26 FCC Rcd 17663, para. 1 (Oct. 27, 2011).

123 In the Matter of Connect America Fund, A National Broadband Plan for Our Future, Establishing Just and Reasonable Rates for Local Exchange Carriers, High-Cost Universal Service Support, Developing an Unified Intercarrier Compensation Regime, Federal-State Joint Board on Universal Service, Lifeline and Link-Up, WC Docket No. 10-90, GN Docket No. 09-51, WC Docket No. 07-135, WC Docket No. 05-337, CC Docket No. 01-92, CC Docket No. 96-45, WC Docket No. 03-109, 26 FCC Rcd 4554, para. 71 (Feb. 8, 2011).

124 See 47 U.S.C. $\$ \S 1301-02$ (2012). 
for those living long distances away from each other or overseas. ${ }^{125}$ Educational resources, like distance or online education initiatives, can require capacity for documents, graphics, and videos in addition to the capability to deliver two-way communications for live chats between students and teachers. ${ }^{126} \mathrm{Ad}-$ vances in telemedicine are constantly improving patients' access to health care even when they are not close to a doctor or hospital. ${ }^{127}$ Remote health monitoring can be especially important for older populations planning to age-inplace. ${ }^{128}$ More and more, people need a broadband connection to do their homework, submit college applications, apply for jobs, access nutritional information, and keep informed about current events in a diverse media marketplace.

Probably due in no small part to broadband service's increasing importance, the number of Internet access connections continues to increase. ${ }^{129}$ Between December 2012 and December 2013, the number of fixed connections with download speeds at or above $3 \mathrm{Mbps}$ and upload speeds at or above $768 \mathrm{kbps}$ increased $21 \%$ to 78 million connections. ${ }^{130}$ The number of wireless connections at those same speeds increased $116 \%$ to 93 million connections in the same time period. ${ }^{131}$ However, the severely limited data caps that often come along with wireless data connections make it difficult to assume consumers can rely solely on wireless connections for all of the important broadband uses discussed above. ${ }^{132}$

125 See President Obama's Plan to Connect Schools Online Affirms Importance of Broadband Adoption for Education, BROADBAND FOR AMERICA (June 7, 2013), http://www.broadbandforamerica.com/blog/president-obama $\% \mathrm{E} 2 \% 80 \% 99 \mathrm{~s}$-plan-connectschools-online-affirms-importance-broadband-adoption-education.

126 See Fed. Commc'ns Comm'n, Connecting America: The National Broadband PLAN 227 (2010).

127 See, e.g., Fed. Commc'ns Comm'n, Health Care Broadband in America: Early ANAlysis AND A PATH ForWARD 5 (2010); CTR. FOR TECH. AND AgIng, TeChNOlOgies FOR Remote PATIENT MONitoring FOR Older ADUlts 13 (2010), available at http://www.techandaging.org/RPMPositionPaper.pdf.

128 CTR. FOR TECH. AND AGING, supra note 127, at 2.

129 Fed. Commc'ns Comm'n, Indus. Analysis and Tech. Division: Wireline Competition Bureau, InTERnet ACCeSS SERVices: Status AS of DeC. 31, 20131 (2014).

130 Id. at 2. Incidentally, 39 million interconnected VoIP connections are bundled with broadband service. FED. COMMC'NS COMM'N, supra note 102, at 7.

131 FED. COMMC'NS COMM'N, supra note 129, at 2.

132 Andrew Odlyzko et Al., Pub. Knowledge, Know Your Limits: Considering the Role of Data Caps and Usage Based Billing in InTernet Access Service 50-52 (2012) (stating that data limits have not changed in over three years, yet an increasing demand for higher data usage in applications such as educational programs where users have to "track each megabyte uploaded and downloaded during the course of a lesson," or in workplace environments where users worry about "hitting caps or punitive overage fees"). 
But the progress in broadband adoption has not been without its wrinkles. ${ }^{133}$ Even as broadband adoption increases, the pace of broadband adoption has slowed substantially over the past few years. ${ }^{134}$ The Pew Research Center's Internet Project has found that broadband adoption increased by an average of seven percentage points per year between 2000 and 2009, but only increased by seven percentage points total from 2009 to $2013 .{ }^{135}$

Increases in broadband adoption are also not uniform between all demographic groups, citing that "demographic factors most correlated with home broadband adoption continue to be educational attainment, age, and household income." ${ }^{136}$ Although the Pew Research Center found that $70 \%$ of American adults reported that they had a wireline broadband connection, ${ }^{137}$ that number fell to $64 \%$ among black respondents and 53\% among Hispanic respondents. ${ }^{138}$ Only $43 \%$ of respondents 65 years and older had an Internet connection, and only $54 \%$ of those with household incomes under $\$ 30,000$ per year were connected. ${ }^{139}$ Educational levels also have a substantial impact on broadband adoption: only $37 \%$ of adults without a high school diploma have Internet access at home, and only $57 \%$ of those with a high school diploma but no college education are connected..$^{140}$ Finally, rural respondents were significantly less likely to have broadband access at home, at $62 \%$, compared to $73 \%$ of suburban respondents. ${ }^{141}$

Broadband Internet access has now become so crucial to the basic economic, civic, and personal lives of users across the country, ${ }^{142}$ policymakers should now ensure the tools they use to achieve universal communications service are also geared toward achieving universal broadband access.

133 See id. at 49-50 (stating that there is a correlation between affordability and adoption, and that "one-third of Americans without broadband cite affordability as a barrier to adoption")

134 Broadband Adoption The Next Mile: Hearing Before S. Comm. On Commerce, Sci, \& Transp., 113th Cong. 1 (2013) (statement of Adam Smith, Senior Researcher, Pew Research Center), available at http://www.pewinternet.org/2013/10/29/statement-of-aaron-smithbroadband-adoption-the-next-mile/.

135 Id.

136 Kathryn Zickuhr, Home Broadband 2013, Pew Res. Center (Aug. 26, 2013), http://www.pewinternet.org/2013/08/26/home-broadband-2013.

137 Id. This study excluded wireless and dial-up connectivity, but did not otherwise exclude any connections from its definition of "broadband" based on speed or usage limits. See id.

$138 I d$.

139 Id.

$140 I d$.

141 Id.

142 David Salway, Why is Increasing Broadband Adoption so Important to Society?, AвоUT.COM, http://broadband.about.com/od/barrierstoadoption/a/Why-Is-IncreasingBroadband-Adoption-So-Important-To-Society.htm (last visited Mar. 14, 2015) (stating that broadband provides educational, civic, and safety advances in modern society). 


\section{METRICS}

Once policymakers have agreed upon certain basic services that should be meaningfully accessible by everyone, there remains the question of how to define and measure those services. What are the metrics by which we will evaluate whether a providers' service actually meets the standards for basic service? How will technology transitions impact basic communications services like voice and Internet access under those metrics? Do these transitions bring opportunities to increase our standards for quality of service? Will the transitions create new challenges in achieving a particular level of quality of service?

After all, just because a technology is newer does not mean it is better in all respects. While a new network technology may bring some advantages like lower deployment costs, ${ }^{143}$ that technology is not a true step forward for everyone if it also abandons technologies that have not yet fully matured, leaving for the possibility that the new technology may fail. ${ }^{144}$ As part of these transitions, therefore, policymakers and stakeholders must more fully understand where new technologies may improve service for consumers and where those technologies must still be improved before we can rely upon them for our communications safety net. ${ }^{145}$

This issue arises regardless of the tools being used to achieve universal service because "broadband services in the market today vary along several important dimensions." ${ }^{146}$ Qualifications for USF recipients, service obligations under COLR rules, and standards for network change proceedings under Section 214 will all necessarily rely on an understanding of how we measure adequate basic service in order to satisfy public interest obligations. ${ }^{147}$

Service metrics are also necessary regardless of the specific type of service at issue as policymakers have now found the extent to which consumers use

143 Ellis Davidson, The Advantages of New Technology for Businesses, CHRON, $\mathrm{http}: / / \mathrm{smallbusiness.chron.com/advantages-new-technology-businesses-4047.html} \mathrm{(last}$ visited Mar. 14, 2015) (stating that while "new technologies can be both a major source of expenses for your business," they can also be a "method of eradicating your biggest costs"). $144 I d$.

145 The Federal Communications Commission has issued a Notice of Proposed Rulemaking soliciting comments on the criteria it should use to evaluate new network technologies when carriers file applications to discontinue service under $\S 214($ a). Customer Premises Equipment Backup Power NPRM, 29 FCC Rcd 14968, para. 93 (Nov. 25, 2014).

146 USF/ICC Transformation Order, 26 FCC Rcd, 17663 para. 90 (Nov. 18, 2011) (stating that while variations exist, a focus on speed latency, and capacity will be used in defining broadband service obligations).

147 Id. at paras. 73-75. 
broadband in terms of download and upload speed. ${ }^{148}$ Indeed, many metrics evaluating the technical parameters and practical efficacy of a service can apply to both voice and Internet access service as voice services now use broadband networks. ${ }^{149}$ Analogous to voice grade access during the 1990s, we have had the goal of universal communications service, now looking at expanding Internet services through broadband and using some similar forms of metrics to measure that service. ${ }^{150}$ For example, the U.S. Postal Service must provide universal mail service, as measured by geographic scope, a suitable range of products, access, delivery services, fair and reasonable rates, quality of service, and user protections. ${ }^{151}$ In telecommunications, the metrics that best measure performance of voice and broadband services may differ slightly, as video demand has become part of the "basic service" expected of broadband, ${ }^{152}$ but whatever the "basic service" is, policymakers must have some way to measure whether consumers are actually receiving that basic service.

Nor is it without precedent for policymakers to establish standards or metrics for measuring service in the telecommunications field as the Commission has considered voice essential since the 1990s ${ }^{153}$ These standards are not necessarily focused on the specific technologies used to deliver a service, but rather delineate aspects of the service itself..$^{154}$ In this sense, one could set out a series of metrics for evaluating basic voice service regardless of whether a carrier uses IP or TDM-based technology to deliver that service. For example, the FCC has adopted a technology-neutral approach for USF recipients. ${ }^{155}$ The FCC requires USF recipients deliver:

[V]oice grade access to the public switched network or its functional equivalent; minutes of use for local service provided at no additional charge to end users; toll limitation to qualifying low-income consumers; and access to the emergency services 911

$148 I d$. at para. 93 (stating that the Commission had found that the ability of a user to download content from the Internet at $4 \mathrm{Mbps}$ and to upload content at $1 \mathrm{Mbps}$ over a broadband network was a reasonable benchmark).

149 See id. at para. 77.

150 Id. at para. 76 (stating that in 1997, the Commission looked to voice grade access to low income customers; however, as times have changed since that point, the Commission has since looked to simplifying those supported services).

151 James I. Campbell, Jr., George Mason Univ. Sch. Of Pub. Pol., Universal SerVice Obligation: History and Development of Laws Relating to the Provision of UNIVERSAL POSTAL SERVICES 6-7 (2008), available at https://www.npes.org/Portals/0/pdf/GM_Study_Universal_Service_App_B.pdf (citing 39 U.S.C. $\S \S 101,403) ; 39$ U.S.C. $\S 101$ (2012); 39 U.S.C. $\S 403$ (2012).

152 USF/ICC Transformation Order, 26 FCC Rcd 17663 para. 93 (stating that along with e-mail and web browsing, high quality video streaming has recently become a "basic service").

$153 I d$. at para. 76.

154 Id. at para. 77

155 Id. at para. 78. 
and enhanced 911 services to the extent the local government in an eligible carrier's service area has implemented 911 or enhanced 911 systems. ${ }^{156}$

Similarly, for example, one can use many of these same standards for broadband access, such implementing a rate ceiling, ${ }^{157}$ whether it is delivered over cable, fiber, or other physical infrastructure, and also include some more broadband-specific metrics where voice and Internet access service differ. Many of the metrics for basic voice service apply to broadband access as well, for example, where a "rate ceiling component charge" would allow a flat rate for residential local service that would provide for flat rate affordable charges so that consumers can still get access to basic service, such as emergency 911 access. ${ }^{158}$ Just as policymakers must investigate network capacity, service quality, interoperability, accessibility, system availability, public safety, security, coverage, and affordability to understand to what extent we have achieved universal voice service, ${ }^{159}$ policymakers would need to use those metrics to evaluate the nation's progress on broadband deployment and availability as well, "which cannot be lost due to technology changes." ${ }^{160}$ In its USF/ICC Transformation Order, the FCC set out three basic metrics for measuring broadband services: actual speed, latency, and capacity (as measured by usage limits). ${ }^{161}$ Meeting minimum requirements on these metrics is crucial to ensuring users have meaningful access to broadband connections that can support key economic, educational, and personal activities.

\section{NETWORK CAPACITY}

To understand whether the network providing voice service is adequate, policymakers must know how much traffic that network can handle, which would "identify the system's real-world 'breaking point." 162 By quantifying a network's "breaking point," network capacity stress tests reveal the limits of the network and help providers and policymakers ensure service will continue to function during periods of high call volume, like holidays and large-scale emergencies. ${ }^{163}$

\footnotetext{
$156 I d$.

157 Id. at para. 914.

158 Id. at paras. 914-16 (stating that a rate ceiling would "help ensure consumer rates remain affordable and set at reasonable levels").

159 Customer Premises Equipment Backup Power NPRM, 29 FCC Rcd 14968, para. 1.

$160 \mathrm{Id}$.

161 USF/ICC Transformation Order, 26 FCC Rcd 17663 para. 88.

162 COlumbia TeleCOMM. CORP., A BRIEF AsSESSMENT OF ENGINEERING Issues Related TO TRIAL TESTING FOR IP TRANSITION 5 (2014), available at https://www.publicknowledge.org/files/CTCPK\%20PSTN\%20Report.pdf. 163 Id.
} 
Network capacity should be measured in the access network, switching, aggregation system, and connections between wire centers to understand strong and weak points in the network during heavy usage. ${ }^{164}$ While the current PSTN has shown high level of availability given that there is sufficient capacity even when the network is at its peak, policymakers should look to confirm that even during these times of peak usage, calls are still routed to the correct locations, calls are completed, call quality does not deteriorate, and call setup does not show noticeable latency. ${ }^{165}$ To do this, stress tests can collect data on the loss or delay of voice packets or jitter in voice calls, call setup time, and call answer delay. ${ }^{166}$

\section{SERVICE QUALITY AND SPEED}

It is also clear that any guarantee of adequate basic service must have some way to ensure adequate service quality to reliably conduct a conversation or transmit data ${ }^{167}$ For voice service, service quality is especially important for those with hearing loss or other disabilities that make users particularly vulnerable to losses in call quality. ${ }^{168}$

\section{CALL QUALITY}

Metrics on call quality can include both quantitative and qualitative measurements. ${ }^{169}$ Qualitative data can include tools like the Delivered Audio Quality (DAQ) score, which helps quantify the qualitative judgments of reviewers. ${ }^{170}$ On the quantitative side, call quality can be measured by frequency response, signal levels, and distortion, with any audible problem leading to a failing score. ${ }^{171}$

Quality testing, especially before migrating customers to new services, is nothing new. ${ }^{172}$ The FCC maintains initial and ongoing performance testing requirements for cable television providers, ${ }^{173}$ and some states required testing

164 Id.

165 Id. at 18

166 Id. at 16 (citing Performance and Stress Testing of SIP Servers, Clients and IP Networks, STARTRINITY, http://startrinity.com/VoIP/TestingSipPbxSoftswitchServer.aspx\#tests (last visited Aug. 18, 2014)).

167 Id.

168 Id.

169 Id.

170 Id. at 7-8.

171 Id. at 8.

172 See, e.g., id. at 7 (explaining that a land-mobile radio testing standard would be applicable).

17347 C.F.R. $\S \S 76.601,76.605$ (a) (2012). 
of up to $40 \%$ of lines during the E-911 transition. ${ }^{174}$ Policymakers can use the lessons learned from these experiences when applying similarly appropriate caution to alterations to the voice network.

\section{SPEED}

Additionally, for Internet access, broadband download and upload speeds make a tremendous difference in what someone is actually able to do with her Internet connection. ${ }^{175}$ Here, the main question for universal service policies is how to maintain an evolving standard for broadband speeds to adequately meet the demands of new network uses.

The FCC has recently updated its standards both for USF recipients' delivered speeds and for its definition of broadband service. ${ }^{176}$ In December 2014, the FCC decided that USF recipients must offer actual delivered speeds (as opposed to advertised speeds) of at least $10 \mathrm{Mbps}$ for downloads and $1 \mathrm{Mbps}$ for uploads. ${ }^{177}$ Even more recently, the FCC has updated its broadband speed threshold past to $25 \mathrm{Mbps} / 3 \mathrm{Mbps}$ for purposes of its Broadband Progress Report. ${ }^{178}$ However, FCC estimates indicate that 1 out of every 6 people in the U.S. lack any access at all to a fixed $25 \mathrm{Mbps}$ or higher connection. ${ }^{179}$ In rural areas, more than $53 \%$ of people lack access to a 25 Mbps connection. ${ }^{180}$

Network users increasingly rely on broadband access to place voice or video calls, stream videos or games, work remotely, and upload and transfer large files through email, cloud storage, or social networks. ${ }^{181}$ In addition, some users

174 See Ill. Admin. Code tit. 83, § 725.500 (2013).

175 Speed Test, MEgAPATH, https://www.speakeasy.net/speedtest/moreinfo.php (last visited Mar. 14, 2015).

176 In the Matter of Connect America Fund; ETC Annual Reports and Certifications; Petition of USTelecom for Forbearance Pursuant to 47 U.S.C. \& 160(c) from Obsolete ILEC Regulatory Obligations that Inhibit Deployment of Next-Generation Networks, Report and Order, WC Docket No. 10-90, 14-58, 14-192, 29 FCC Rcd 15644, para. 62, 63 (Dec. 11, 2014); Id. at 90, 97 (Statement of Chairman Wheeler).

177 Id. at para. 4.

178 In the Matter of Inquiry Concerning the Deployment of Advanced Telecommunications Capability to All Americans in a Reasonable and Timely Fashion, and Possible Steps to Accelerate Such Deployment Pursuant to Section 706 of the Telecommunications Act of 1996, as Amended by the Broadband Data Improvement Act, Broadband Progress Report, FCC 15-11, GN Docket No. 14-126, GN Docket No. 12-228, at 4 (Feb. 4, 2015) (Statement of Chairman Wheeler) [hereinafter Deployment of Advanced Telecom Capacity Broadband Progress Report].

179 Id.

180 Id.

181 SAndvine Intelligent Broadband Networks, Global Internet Phenomena REPORT 5-6 (2014), available at https://sandvine.com/downloads/general/global-internetphenomena/2014/1h-2014-global-internet-phenomena-report.pdf; Digital Differences, PEWINTERNET.ORG 11-12 (2012), http://pewinternet.org/Reports/2012/Digital- 
are starting to use "connected home" devices like security alarms, thermostats, door locks, and home appliances. ${ }^{182}$

Broadband access inspires more ideas for more uses of broadband networks, and users' need for greater speeds only continue to increase. ${ }^{183}$ The total number of fixed and mobile connections with speeds less than $6 \mathrm{Mbps} / 1.5 \mathrm{Mbps}$ actually decreased 8.8\% between December 2012 and December 2013, from 190.3 million connections to 173.6 million, while connections greater than or equal to $6 \mathrm{Mbps} / 1.5 \mathrm{Mbps}$ increased $66 \%$ from 72.3 million to 119.7 million. ${ }^{184}$ The number of connections with downstream speeds of $10 \mathrm{Mbps}$ or greater has increased 104\% since December 2012, totaling 122 million connections. ${ }^{185}$

In addition to call quality and speed, latency ${ }^{186}$ can be a useful measure of the service quality delivered by communications technology. Latency is especially important for real-time communications, including two-way voice and video services. ${ }^{187}$ The FCC's broadband measurement test results found that most wireline networks could reliably achieve latency of less than 100 milliseconds. ${ }^{188}$

\section{DEVICE INTEROPERABILITY}

Device interoperability has become one of the hallmarks of the traditional phone network - one that also proved an important precedent for the develop-

differences.aspx (last visited Mar. 14, 2015); DARRELl M. WeSt, CTR. FOR TECH. INNOVAtion at Brookings, The Evolution of Video Streaming and Digital Content DelivERY $1-2 \quad$ (2014), available at http://www.brookings.edu/ /media/research/files/papers/2014/05/02\%20video\%20streamin g/west_evolution $\% 20$ of $\% 20$ videostreaming\%20and $\% 20$ digital $\% 20$ content $\% 20$ delivery_fin al.pdf.

182 Claire Cain Miller, Is 2014 the Year of the Connected Home?, N.Y. Times Bits (Jan. 3 , 2014), http://bits.blogs.nytimes.com/2014/01/03/is-2014-the-year-of-the-connectedhome; Cisco, Cisco Visual Networking Index: Global Mobile Data Traffic Forecast UPDATE, 2014-2019 3 (2015), available at http://www.cisco.com/c/en/us/solutions/collateral/service-provider/visual-networking-indexvni/white_paper_c11-520862.pdf.

183 CisCO, supra note 182.

184 FED. COMMC'NS COMM'N, supra note 102, at 2 (Figure 1). It is worth noting here that the connection speeds in this report are often the advertised speeds, regardless of the actual delivered speed at any given moment. $I d$. at n.1.

185 Id. at 4.

186 Latency is a "measure of the time it takes for a packet of data to travel from one point to another in a network," often measured by the milliseconds necessary for a round-trip. USF/ICC Transformation Order, 26 FCC Rcd 17663 para 96.

187 Id.

188 See Fed. Commc'ns Comm'n, Office of Eng'G and Tech. And Consumer And Gov't Affairs Bureau, Measuring Broadband America, A Report on Consumer Wireline BROADBAND PERFormanCE IN THE U.S., 22 (2011) (Chart 9). 
ment of wireline Internet access service. ${ }^{189}$ One recent survey found that, of the respondents who continue to keep a traditional landline phone service, $26 \%$ do so because they need it for a fax machine, $24 \%$ need the line to use medical alert services, and $17 \%$ use the line for a home security system. ${ }^{190}$ Especially given consumers' strong expectations that certain voice and non-voice devices will just work on the phone network, regardless of the network's underlying technology, ${ }^{191}$ it is important to verify that devices will continue to function on new networks and make customers whole when devices will no longer work.

If existing devices will not operate on new networks, network users across the country would be facing serious consequences and substantial costs. ${ }^{192}$ Whether a particular type of device will not work at all on a new network, or customers will need to purchase a new version of the device to continue using the same functionality, the transition would impose significant costs on users and businesses that policymakers should be aware of. ${ }^{193}$

For interoperability in voice devices, policymakers can test analog telephone adapters (ATAs) to ensure they can work with voice devices and standard jacks. ${ }^{194}$ Policymakers can also determine whether a new technology will impact non-voice devices like fax machines, credit card/point-of-sale terminals, ATMs, voting machines, medical monitoring and alert systems, security alarms, elevator phones, ringdown lines at fire stations, and intercoms for building access, by testing the full range of standard modem protocols. ${ }^{195}$

\section{ACCESSIBILITY}

The technology transitions present opportunity to take advantage of new technologies to increase accessibility for network users, in addition to preserving the functionality the network offers now. ${ }^{196}$ Individuals with disabilities rely on specialized devices and services like Telecommunications Relay Services (TRS), Telecommunications Devices for the Deaf (TDD), and Text Telephones (TTY) to communicate over the network. ${ }^{197}$

\footnotetext{
189 Interoperability Systems, CiSCO, http://www.cisco.com/c/en/us/products/physicalsecurity/interoperability-systems/index.html (last visited Mar. 14, 2015).

190 HORRIGAN, supra note 13, at 7.

191 Id.

192 U.S. Cellular Device Unlocking Policy, U.S. CELlular, http://www.uscellular.com/site/legal/mobile-wireless-device-unlocking.html (last visited Mar. 14, 2015).

193 Id.

194 Columbia Telecomm. CoRP., supra note 162, at 12.

195 Id.

196 Id. at 16.

197 Id. at 15.
} 
Both the TTY/TDD system and the TRS system are well-established technologies that allow users to communicate via text over the phone network. ${ }^{198}$ Other text- or video-based communications often require a wireless or wireline broadband connection, and therefore are less accessible to users who do not have access to a high-enough quality connection or cannot afford it. ${ }^{199}$

Any new network technology should therefore be examined to determine how and whether it will interoperate with TTY/TDD and TRS service. TTY/TDD service in particular relies on analog telephone modem technology, which may make it less reliable during times of heavy network usage ${ }^{200} \mathrm{~A}$ network transition would therefore require examination of the potential points of failure for the majority of TTY/TDD devices in use (not just those currently for sale), including qualitative and quantitative testing for users' ability to connect, place calls, and send and receive messages. ${ }^{201}$

\section{SYSTEM AVAILABILITY}

The traditional phone network was intentionally designed and governed to deliver a high level of availability for customers. ${ }^{202}$ The copper lines received power through the central office, helping to ensure operation even during commercial power outages. ${ }^{203}$ The network was designed to have enough capacity to connect users even during peak demand. ${ }^{204}$ Interconnection ensured customers could reach any other network user, regardless of location or carrier choice. $^{205}$

A system availability test could determine whether a new network technolo-

198 Id. at 16.

199 Id. at 15.

200 Id. at 16.

$201 \mathrm{Id}$.

202 See Internet Soc'y, The Internet And the Public Telephone Switched NetWORK: DISPARITIES, DIFFERENCES, AND DISTINCTIONS 2 (2012), available at http://www.internetsociety.org/sites/default/files/The\%20Internet\%20and\%20the $\% 20$ Public $\% 20$ Switched\%20Telephone\%20Network.pdf (describing the structure of network switching offices that provided the capability of the telecommunications system to host a large amount of users)

203 Jon Brodkin, FCC to prevent phone companies from screwing over copper customers, ARs TEChNICA (Nov. 21, 2014, 2:45 PM), http://arstechnica.com/business/2014/11/fcc-toprevent-phone-companies-from-screwing-over-copper-customers/ (comparing copper lines and VoIP); COlumbia TeleCOMM. CoRP., supra note 162, at 18.

204 COLUMBIA TELECOMM. CORP., supra note 162, at 18.

20547 U.S.C. § 251(c)(2) (2012); see ENERGY AND COMMERCE COMM., NeTwork InTERCONNECTION 12 available at http://energycommerce.house.gov/sites/republicans.energycommerce.house.gov/files/analys is/CommActUpdate/20140715WhitePaper-Interconnection.pdf ("Incumbent local exchange carriers...were obligated by the Act to negotiate in good faith for interconnection of traditional, circuit switched traffic at any technically feasible point in their network."). 
gy could deliver the same level of availability that the existing network infrastructure did. ${ }^{206}$ With IP-based technology, the system's availability can be tested non-intrusively, so tests can poll ATA devices or use another monitoring functionality to document network availability and outage causes ${ }^{207}$ These tests should also note the times of incidents like commercial power outages, storms, Internet outages, or times of high network usage, to better examine possible causes of network downtime. ${ }^{208}$

\section{PUBLIC SAFETY COMMUNICATIONS}

One of the most crucial functionalities of the phone network is the ability to call for help during times of emergency. ${ }^{209}$ Unsurprisingly, 96\% of respondents to one recent survey said that it is important for phones to be able to reach emergency services like $911 .{ }^{210}$ Policymakers cannot take for granted that new technologies will always offer the public the same access to 911 service, so new technologies must be tested to ensure calls to 911 reliably go through and public safety answering points can reliably and quickly access callers' locations. ${ }^{211}$

Traditional landline phone service gives people reliable access to 911 and public safety answering points (PSAPs), and provides PSAPs with dispatchable location information to help public safety workers find callers even if the caller cannot tell the operator his or her location. ${ }^{212}$ But it still remains to be seen how policymakers will ensure new technologies will offer those same public safety guarantees to users. ${ }^{213}$ For example, wireless technologies may

206 Columbia TeleCOMM. CORP., supra note 162, at 18.

207 Id. at 19.

208 Id.

209 Id. at 20.

210 HORRIGAN, supra note 13, at 10 (finding that $59 \%$ of respondents stated that it is important "that their phone have the capability to communicate their location" for purposes like 911 location technologies).

211 See COlumbia TeleCOMM. CORP., supra note 162, at 20 (listing the variety of test scenarios to which new telecommunications technologies should be subjected to ensure reliable access to emergency services).

212 INTRADO, INC., PSAP OPERATIONS GUIDE FOR WIRELESS 9-1-1 2 (2005), available at http://www.intrado.com/sites/default/files/documents/PSAP_Operations_Guide_for_Wireles s_9-1-1.pdf.

213 See NEnA Next Generation Partner Program, NG9-1-1 Transition Policy BRIEF $1, \quad 3, \quad$ available at https://c.ymcdn.com/sites/www.nena.org/resource/collection/B6781C63-012C-4E90-939B001733976BBC/NG9-1-1_Transition_Policy_Considerations-ALI.pdf ("Policy makers need to ... effectively promote innovation while ensuring the reasonable 9-1-1 expectations are met" and they should "actively support the development of nationally recognized standards and best practices to ensure effective automatic 9-1-1 location capabilities are put into place for all technologies and services as they go to market"). 
offer new or greater problems with reliability, coverage, and congestion during large-scale emergencies. ${ }^{214}$ Wireless service also does not currently provide PSAPs with the same dispatchable location data as the traditional landline phone network did. ${ }^{215}$ Testing for new network technologies should therefore include verifying that users can complete 911 calls and reach the correct PSAP, and that PSAP staff can provide the same level of response to a caller on the new network as on the existing network. ${ }^{216}$

\section{SECURITY}

The IP transition has already brought with it VoIP denial-of-service attacks on PSAPs, resulting in large numbers of calls overloading the PSAPs' capacity and obstructing true emergency calls. ${ }^{217}$ To protect the network from attacks and preserve functionality for users' legitimate calling needs, policymakers must determine the degree to which a new network is vulnerable to attack, the presence of points of failure, and users' ability to impersonate other users, maliciously disconnect other devices, or generate spoofed calls. ${ }^{218}$ Independent experts could review carriers' reports of how they address security issues, and examine whether those efforts comply with industry best practices and with the Cybersecurity Framework developed as part of Executive Order 13636, Improving Critical Infrastructure Cybersecurity. ${ }^{219}$ Policymakers could even use "white hat" external tests to determine the level of risk without actually damaging the network. ${ }^{220}$ Meanwhile, best practices like using separate "tunnels" for voice communications and system management could help secure the network. $^{221}$

\footnotetext{
214 See Columbia Telecomm. Corp., supra note 162 (stating that the complexity of an IP system exacerbates the problems associated with high network traffic).

215 INTRADO, INC., supra note 212 ("With the advent of wireless telecommunications-and its inherent mobility-the 'who' and 'where' were no longer associated with the caller's telephone number."); see generally In the Matter of Wireless E911 Location Accuracy Requirements, Third Further Notice of Proposed Rulemaking, PS Docket No. 07-114, 29 FCC Rcd 2374 para. 2 (Feb. 21, 2014) (stating that a change of the public's use of mobile phones has caused the FCC to consider rules to increase location accuracy standards for 911 calls made from mobile phones indoors).

216 COLUMBIA TELECOMM. CORP., supra note 162, at 20-21.

217 Id. at 23 (citing David Kahn, The Growing Threat to PSAPs from Telephony Denial of Service (TDoS) Attacks, 9-1-1 Magazine (July 3, 2013), http://www.9-11 magazine.com/Kahn-Threat-of-TDoS-Attacks.

218 Id.

219 Id. at 23-24; see generally Improving Critical Infrastructure Cybersecurity, 78 Fed. Reg. 11,739 (Feb. 19, 2013).

220 Columbia TeleCOMm. CorP., supra note 162, at 23.

221 Id. at 24 .
} 
Particularly as voice communications increasingly share infrastructure with the broader Internet, carriers and policymakers will need to be vigilant against cybersecurity risks to ensure basic voice service cannot be hacked to harass or harm network users.

\section{CALL PERSISTENCE}

The wireline phone network's reliability led to the common expectation that calls will almost never be "dropped." 222 Indeed, the landline network offered such great reliability it encouraged the development of devices and features that require persistent connectivity to function, like health and security monitoring services. ${ }^{223}$ Especially in the early days of commercial mobile phone service, call persistence on the wireline network was one of the distinguishing features between landline and cell phone service. ${ }^{224}$ Call persistence in wireless phone service varied enough that it became marketing point between companies, as opposed to a feature of the service that everyone could safely take for granted. ${ }^{225}$

To understand how often a network drops calls, policymakers can measure "how long a call persists under a range of circumstances." ${ }^{226}$ If there are no call persistence problems, calls should be able to stay connected for one week. ${ }^{227}$ Any calls that are dropped can be examined for the root cause and necessary modifications can be made to the network to ensure calls are not dropped.

\section{CALL FUNCTIONALITY}

For several basic functions of the phone network, consumers have relied on certain features for so long, it does not even occur to customers that changing to a new technology could compromise their service. ${ }^{228}$ For example, people take for granted that their phone connections will always give them the ability to connect to any other phone customer, regardless of which carrier that customer uses. ${ }^{229}$

222 Id.

${ }^{223}$ See id. (stating that connection reliability is required for monitoring applications).

224 Id.

225 See Theresa Howard, 'Can You Hear Me Now?' a Hit, USA Today (Feb. 23, 2004, 10:30 PM), available at http://usatoday30.usatoday.com/money/advertising/adtrack/200402-22-track-verizon_x.htm.

226 COlUMBIA TELECOMM. CORP., supra note 162, at 24.

227 Id.

$228 C f$. id. at 25 ("There is no technological reason why a user should lose basic functionality simply because of IP migration.").

229 Id. 
There is no technological reason that basic functionalities like this should fall away during transitions that should by all accounts be an upgrade in technology, nor should we assume that new technologies must necessarily result in closed proprietary systems instead of the open, innovative structures. ${ }^{230}$ When, for example, network transitions result in carriers placing greater restrictions on customers' ability to reach other networks, new limitations should raise a red flag for policymakers evaluating the public interest impacts of the transitions. ${ }^{231}$

To understand network changes' implications for users, policymakers must test the full range of user functions that currently rely upon the network, including transport of caller-ID information, the ability to reach outside carriers' networks, and making and receiving collect calls and third-party billed calls. ${ }^{232}$

\section{WIRELINE COVERAGE}

It is not inconsistent for policymakers to both commit to being technologyneutral and to acknowledge that wireline service currently offers certain features that wireless networks do not. ${ }^{233}$ Until wireless technology has developed to the point where it truly offers equal or better service than the wireline network on all fronts, wireline coverage will necessarily be of concern to policymakers. ${ }^{234}$

For example, when Verizon responded to the damage caused by super-storm Sandy by migrating customers from the copper network to the fixed, voiceonly wireless service Voice Link, many customers objected that Voice Link was inferior to the copper-based service in many respects. ${ }^{235}$ Even outside the

230 Id.

231 See, e.g., Letter from Joseph A. Post, Deputy Gen. Counsel, Verizon, to Honorable Jeffrey C. Cohen, Sec'y, N.Y. State Pub. Serv. Comm. (May 20, 2013), available at https://www.publicknowledge.org/files/VZ\%20Voice\%20Link\%20TOS.pdf (containing Verizon's Voice Link Terms of Service, which notified customers of limited access to long distance providers, international phone service providers, and calling card services).

232 Columbia TeleCOMM. CORP., supra note 162, at 25-26.

233 See generally Peter Alexadis \& Miranda Cole, The Concept of Technology Neutrality, in Euro. Competitive Telecomm. Ass'N ReV. 76, 77

(2004), available at http:/www.gibsondunn.com/fstore/documents/pubs/AlexiadisECTA_Review_2004.pdf (stating that the technology-neutral concept should be applied with the "concepts of substitutability and functional interchangeability"; however, wireline and wireless services are not functionally interchangeable, because they do not offer all of the same services).

234 See, e.g., Herman Watger, 3G/4G as a Landline Data Substitute, FIBER EVOLUTION (Sept. 10, 2014), http://www.fiberevolution.com/2014/09/3g4g-as-a-landline-datasubstitute/ (noting that in the context of just broadband service, data caps, capacity, and service quality continue to differentiate most commercially available wireless and wireline services).

235 See PuB. KNOWLEDGE, supra note 116 (stating that hundreds of customer complaints 
realm of natural disaster response, customers have complained that carriers are delaying repairs to the copper network or only providing temporary repair solutions. $^{236}$

Policymakers could determine levels of wireline service by physically verifying service and confirming that those locations are actually able to receive service. $^{237}$

\section{AFFORDABILITY}

Ultimately, a service cannot be universal if people cannot afford to adopt it. Even if service is technically available, service that is priced out of the reach of customers' budgets is not available in any meaningful sense of the word. Universal service means everyone must be realistically able to obtain service, not just wealthy households or neighborhoods. ${ }^{238}$ If, for example, a carrier is required to provide service but permitted to charge a very large Contribution in Aid of Construction (CIAC), that can effectively prevent service from reaching hard-to-serve areas. ${ }^{239}$

Policymakers therefore must investigate and document pricing trends to be able to determine whether pricing for new technologies is comparable to what customers pay for existing technology. In this respect it is important to watch not just for overall price increases, but for differences in payment structures or functionality that can impact the value customers are receiving for their mon-

were received by Verizon on this matter).

236 See Jon Brodkin, Verizon Accused of Refusing to Fix Broken Landline Phone Service, ARs TECHNICA (Mar. 23, 2014, 4:32 PM), http://arstechnica.com/informationtechnology/2014/03/verizon-accused-of-refusing-to-fix-broken-landline-phone-service/;

Carolyn Shapiro, With aging infrastructure, Verizon has trouble on the line, PILOT ONLINE (Oct. 24, 2011), http://hamptonroads.com/2011/10/aging-infrastructure-verizon-has-troubleline.

237 See Columbia Telecomm. CorP., supra note 162, at 26-27 (explaining the methodology of the physical verification process).

238 See Dep'T of Commerce, Econ. And Statistics Admin. \& NTIA, Exploring the Digital NATion: AmericA's EMERging Online EXPERIENCE 36 (2013), available at http://www.ntia.doc.gov/files/ntia/publications/exploring_the_digital_nation_-

americas_emerging_online_experience.pdf (stating that $8 \%$ of the highest earning households without home Internet reported having other outside means of Internet access, while only $2 \%$ of households earning less than $\$ 25,000$ annually reported similar opportunities); John Horrigan, Joint CTR. For Political ANd ECON. STUdies, BroAdBand Adoption AND USAge: What HAS Four YeARS TAUght Us? 2 (2013), available at http://moody.utexas.edu/sites/communication.utexas.edu/files/images/content/tipi/Horrigan. FCC_.Summit.02.06.pdf (demonstrating that price is one of the most common reasons why people cannot subscribe to broadband access service).

239 See Peter Bluhm \& Phyllis Bernt, PhD, Carriers of Last Resort: Updating A Traditional Doctrine, NAT'L REg. RES. InST. 8-9 (July 2009), available at http://www.nrri.org/pubs/telecommunications/COLR_july09-10.pdf. 
ey. ${ }^{240}$ For example, new below-the-line fees are effectively price increases in all but name, ${ }^{241}$ and services that nominally cost the same but offer fewer features or inferior service do not offer truly comparable value. Policymakers should also document whether and to what extent customers have access to a variety of price points and service levels, ${ }^{242}$ and watch for practices that could push customers to purchase more than what they want or need.

It is also possible that new technologies will offer the opportunity for lower retail prices. ${ }^{243}$ Carriers have certainly touted the cost savings offered by new technologies ${ }^{244}$ and with sufficient competitive pressure those savings could be passed on to consumers. ${ }^{245}$ And as technology further improves, these cost savings may even be paired with improvements in service. ${ }^{246}$ Policymakers could use the pricing data discussed above to better understand and seize opportunities to make basic service more affordable for consumers.

The metrics for interconnected voice and broadband service have significant overlap. ${ }^{247}$ If policymakers use these metrics to develop a set of standards for

\footnotetext{
240 See Thomas Gryta, AT\&T Imposes New 61-Cent Monthly Wireless Fee, WALL STREET J. (May 23, 2013), available at http://online.wsj.com/news/articles/SB10001424127887323975004578501330496021310.

241 See, e.g., id.

242 See, e.g., Fed. Commc'ns Comm'n, National Broadband Plan: Connecting AMERICA 39 (2010), available at http://www.broadband.gov/plan/4-broadband-competitionand-innovation-policy/ (concluding that "better data" is required to analyze "price competition").

${ }^{243}$ See, e.g., Matthew Flamm, Super-fast Internet is here. What to do with it?, CRAIN's: N.Y. Bus. (Feb. 24, 2015, 9:00 AM), http://www.crainsnewyork.com/article/20150224/TECHNOLOGY/302229997/super-fastinternet-is-here-now-what-to-do-with-it (discussing a Brooklyn startup that provides gigabit broadband Internet service at a fraction of the traditional price).

244 See In the Matter of AT\&T Petition to Launch a Proceeding Concerning the TDM-toIP Transition, Petition to Launch a Proceeding Concerning the TDM-to-IP Transition, GN Docket No. 12-353, at 4 (Nov. 7, 2012); see generally In re AT\&T Petition to Launch a Proceeding Concerning the TDM-to-IP Transition, Comments of Verizon and Verizon Wireless, GN Docket No. 12-353 (Jan. 28, 2013).

245 See LTE and Wireless Service Assurance, Monolith SOFTwARE, http://www.monolith-software.com/solutions/telecommunications-and-cable/lte-andwireless-service-assurance (last visited Mar. 13, 2015) ("With LTE, IMS and other wireless technology upgrades accelerating, the resulting competitive pressures have made it imperative for service providers to take a customer-centric and end-to-end view of mobile and fixed services, focusing on customer experience management (CEM) and service assurance.").

246 See Flamm, supra note 243.

247 See, e.g., In re The Proposed Extension of Part 4 of the Commission's Rules Regarding Outage Reporting to Interconnected Voice Over Internet Protocol Service Providers and Broadband Internet Services Providers, Comments of the Telecommunications Industry Association, PS Docket No. 11-82, at 6 (Aug. 9, 2011) (urging adoption of the metrics proposed in the SamKnows, which provide consistent factors for determining outages for both VoIP and Broadband services).
} 
"basic" voice and broadband service, stakeholders on all sides will know what to expect during new build-outs and network changes. Carriers will be able to plan their investment knowing what will be expected of them, and end users will know they can depend on a network that will offer at least a certain level of service and support certain features.

\section{TOOLS TO ACHIEVE UNIVERSAL SERVICE}

Once policymakers have committed to ensuring universal access to voice and broadband service, and determined the metrics by which to evaluate what the "basic service" is and whether it is actually being delivered, the question still remains of how to actually achieve that goal. The "how" of universal service has been debated by stakeholders and policymakers for over 100 years now, ${ }^{248}$ and this paper makes no pretense of solving the puzzle for good, but will instead review the tools, new and old, that policymakers could use to ensure universal deployment of basic voice and broadband service.

Congress already requires the FCC to annually investigate whether "advanced telecommunications capability" is available to all Americans and whether "advanced telecommunications capability is being deployed to all Americans in a reasonable and timely fashion. ${ }^{249}$ In the FCC's most recent Notice of Inquiry on broadband deployment pursuant to Section 706, the agency identified several tools already at its disposal to encourage broadband deployment and access, including "price cap regulation, regulatory forbearance, measures that promote competition in the local telecommunications market, or other regulating methods that remove barriers to infrastructure investment. ${ }^{250}$ Separately, the FCC is considering whether to preempt certain state laws that restrict local governments' ability to offer broadband service. ${ }^{251}$ These and oth-

\footnotetext{
248 See generally, Mann-Elkins Act of 1910, ch. 309, 36 Stat. 539 (1910) (attempting to establish universal service in the message transmission across "telegraph, telephone, or cable").

24947 U.S.C. $\S 1302$ (a) (2012).

250 See In the Matter of Inquiry Concerning the Deployment of Advanced Telecommunications Capability to All Americans in a Reasonable and Timely Fashion, and Possible Steps to Accelerate Such Deployment Pursuant to Section 706 of the Telecommunications Act of 1996, as Amended by the Broadband Data Improvement Act, Tenth Broadband Progress Notice of Inquiry, GN Docket No. 14-126, 29 FCC Rcd 9747 para. 49 (Aug. 5, 2014) (quoting 47 U.S.C. § 1302(a) (2012)) [hereinafter Deployment of Advanced Telecommunications NOI].

251 See Pleading Cycle Established for Comments on Electric Power Board and City of Wilson Petitions, Pursuant to Section 706 of the Telecommunications Act of 1996, Seeking Preemption of State Laws Restricting the Deployment of Certain Broadband Networks, Public Notice, DA 14-1072, 29 FCC Rcd 9239 (July 28, 2014).
} 
er tools could have tremendous impact on the efforts of the U.S to achieve universal voice service, broadband service, or both. ${ }^{252}$

\section{CARRIER OF LAST RESORT POLICIES}

Carrier of last resort (COLR) policies have been a critical component of our national commitment to universal service for decades. ${ }^{253}$ Particularly at the state level and for companies receiving support through Universal Service Fund programs, COLR rules have guaranteed that virtually everyone in the country could receive basic voice service upon request. ${ }^{254}$ By requiring carriers to serve all requesting customers in their service areas, COLR rules imposed significant constructions costs on carriers (which could be offset by government funding mechanisms or reimbursement by customers in certain circumstances) as a condition of entering the common carrier business of telephony service. ${ }^{255}$ This approach proved to be wildly successful and resulted in near universal nationwide voice service..$^{256}$

Traditionally, COLR responsibilities have been assigned to local exchange carriers $^{257}$-responsibilities that included a duty to provide reasonable quality service on request, ${ }^{258}$ not discriminating against any prospective customers, ${ }^{259}$ offering service at rates set or approved by state authorities, ${ }^{260}$ and seeking advance approval for any significant network change, sale, or exit. ${ }^{261}$ At both the state and federal levels, COLRs also have the obligation to interconnect with

252 See Deployment of Advanced Telecommunications NOI, 29 FCC Rcd 9747 para. 49 (explaining that pursuant to 47 U.S.C. $\S 1302$ (a) the Commission has authority to take measures to ensure competition throughout the broadband infrastructure when United States citizens are not receiving reasonable and timely access to broadband services).

253 See BluhM \& BERNT, PHD, supra note 239, at 1.

254 See id.

255 See id. at 4-5, 8.

256 See Jeff Lanning, Centurylink, The COlR Challenge, Broadband, and Rural $\begin{array}{lllll}\text { AMERICA } & 5 & (2010), & \text { available }\end{array}$ http://www.narucmeetings.org/Presentations/NARUC\%20COLR\%202010-11-14.pdf.

257 See Bluhm \& BERNT, PhD, supra note 239, at 2. Some states automatically classify all incumbent local exchange carriers as COLR, and many states exempt competitive local exchange carriers from COLR responsibilities. Other states assign COLR or COLR-like duties to any LEC that becomes an eligible telecommunications carrier. See id. at 3.

258 See id. at 5 n. 13 (providing 16 N.Y.C.R.R. § 609.3(a)(1)); see, e.g., tit. 16, part 2 Tex. Admin. Code $\S 26.54(b)(1)$ (2015); see, e.g., WASH. Rev. CodE $\S 80.36 .090$ (examples of state imposed duties to serve the public upon request).

259 See 47 U.S.C. $§ 251(\mathrm{~g})(2012)$ ("[E]ach local exchange carrier, to the extent that it provides wireline services, shall provide...in accordance with the same equal access and nondiscriminatory interconnection restrictions and obligations...."); BLUHM \& BERNT, PHD, supra note 239, at iii.

260 See BlUhM \& BerNT, PHD, supra note 239 , at iii.

261 Id. 
other carriers, which ensures that every phone on the network could call every other phone. ${ }^{262}$

COLR policies typically cover retail service quality standards, like dial tone availability, call blocking rates, outage times, customer complaint rates, response time to complaints, and emergency service continuance plans. ${ }^{263}$ COLRs may also be required to offer certain consumer protections and other guarantees, like participating in the federal Lifeline program, providing certain disclosures, offering trial periods, providing specified cancellation terms, taking steps to maintain power during blackouts, and allowing even disconnected customers to make 911 calls. ${ }^{264}$

As we are now in the midst of the technology transitions, and the questions arise of whether and how COLR policies could be used to serve the same social goals that they have been used for in the development of the traditional phone network. ${ }^{265}$ Particularly when paired with other efforts, like voluntary build-out and affordability programs and universal service funding, policymakers may want to consider adopting some of the strategies of COLR to prevent low-income or high-cost areas from being left behind in the transitions. ${ }^{266}$

In these policy debates, it should be noted that even robust competition in urban and suburban areas would not entirely eliminate the need for COLR duties. ${ }^{267}$ After all, the areas where COLR is most needed are the areas where there is no business case to build out and maintain the networks, so competition will necessarily be lacking. ${ }^{268}$ Competition may give users more choice in some areas, but on its own could result in no service for high-cost or lowincome areas. ${ }^{269}$ However, even in areas with competitive choices, market forces may not on their own give carriers sufficient incentive to offer customers all of the benefits of COLR policies. Even a competitive telecommunications

262 Id. at iii, 2.

263 Id. at 64; see generally LiLia PÉREZ-Chavolla, NAT'L Regulatory ReSEARCH Inst., Survey of State Retail Telephone Quality of Service Regulations for Selected Categories of Service: Metrics, Penalties And Reports (2004), available at http://nrri.org/pubs/telecommunications/04-09.pdf (providing state specific examples of service quality standards).

264 See BluHM \& BernT, PhD, supra note 239, at 7-8, 11

265 See Intergovernmental Advisory Comm. To the Fed. COMmC'ns Comm'n, PoliCy Recommendation 2013 - 3: Regarding TeChNOlogical Transition From Legacy COPPER Wire Infrastructure tO NEWER TEChNOlOGIES 1 (2013), available at http://transition.fcc.gov/statelocal/recommendation2013-03.pdf ("In a competitive environment in which wire, wireless, IP-based, satellite and other technologies exist to move voice and data communications, a legitimate question exists as to whether the requirement for a designated carrier of last resort should remain.").

266 See id. at 2.

267 See Bluhm \& Bernt, PhD, supra note 239, at 56.

268 See LANning, supra note 256, at 3, 5, 7.

269 See BluHM \& BERNT, PHD, supra note 239, at 56-57. 
market may have inadequate transparency, ${ }^{270}$ and each individual carrier may have little incentive to serve important but less-frequent needs of particular user groups, like users with disabilities or consumers relying on security devices or heart monitors, support for which could fall by the wayside without policies ensuring their needs continue to be served. ${ }^{271}$

The FCC has declined to preempt state obligations, including COLR requirements, in its USF/ICC Transformation Order. ${ }^{272}$ Some have suggested that states update traditional doctrines by, for example, assigning relatively large service areas to ETCs, adapting COLR duties to anticipate multi-subscriber properties and competitive overbuilds, differentiating between COLR duties and duties for supported ETCs, giving wireless and broadband subscribers separate ETC designation, and providing universal service support to COLRs. ${ }^{273}$

Some have also suggested that states may want to consider applying COLR responsibilities to broadband service providers in addition to voice service providers. ${ }^{274}$ The concept of requiring COLRs to provide some level of computer data transmission using a modem is not unprecedented, ${ }^{275}$ although the required transmission levels have not met what we would consider adequate broadband service today. ${ }^{276}$

The need for policies to ensure ubiquitous and nondiscriminatory broadband access seems to only be growing. ${ }^{277}$ Even as the number of broadband connections continues to increase, the demographic disparities between the broadband haves and have-nots continue. ${ }^{278}$ The FCC's most recent Internet Access Services Report found that there are only 43 residential fixed broadband connections (defined as a speed of at least $200 \mathrm{kbps}$ in either direction) for every 100 households in the bottom decile of counties, sorted by income. ${ }^{279}$ Notably, this

270 See Fed. Commc'Ns Comm'N, supra note 242, at 44 ("Putting more information in the hands of consumers is a proven method to promote meaningful competition....").

271 See id. at 167-69.

272 USF/ICC Transformation Order, 26 FCC Rcd 17663 para. 82 (Oct. 27, 2011).

273 See Bluhm \& Bernt, PhD, supra note 239, at iv-v.

274 See Phyllis Bernt, Universal Service in the National Broadband Plan: A Case for Federal-State Cooperation, 1 J. OF INFO. POL'Y 125, 133-34 (2001) (explaining the various possible uncertainties that states would encounter when applying COLR responsibilities to broadband providers).

275 See, e.g., TEX. ADMIN. CODE. tit. 16, part 2, § 26.54(b) (requiring transmission at 14,400 bits per second); see, e.g., WIS. ADMIN. CODE. PSC, $\S 160.031$ (requiring 9,600 bits per second).

276 See Bernt, supra note 274, at 131.

277 See, e.g., Angele A. Gilroy, Cong. Research Serv., R40616, Access to BroadBAND Networks: The Net NeUtrality Debate 1 (2015), available at http://fas.org/sgp/crs/misc/R40616.pdf (discussing the New Neutrality debate, at which access to broadband absent discrimination is central).

278 See Office of Sci. and Tech. Policy \& the Nat’l Econ. Council, The White HOUSE, REPORT: FOUR YEARS OF BROADBAND GROWTH 4 (2013).

279 See FED. COMMC'NS COMM'N, supra note 129, at 66 (Chart 17). 
is actually lower than the subscribership ratios for the bottom decile of households in June 2013 and December 2012. ${ }^{280}$ In contrast, the top decile of counties by income had 83 fixed connections for every 100 households- $-93 \%$ more than the number of connections in the lowest decile. ${ }^{281}$ Similarly, counties with the largest share of college graduates had 81 residential fixed connections for every 100 households, while counties with the lowest share of college graduates had only 48 connections per 100 households - $69 \%$ fewer connections than the most-educated counties had. ${ }^{282}$

If policymakers - whether at the federal or state level—look to a COLR approach for universal service policy in new technologies, specific aspects of existing COLR rules could help give at least a starting point for thinking through what specific rules might look like. For example, line extension rules under COLR regimes could also be informative for broadband universal service policy. ${ }^{283}$ Often COLRs are permitted to charge a Contribution in Aid of Construction (CIAC), ${ }^{284}$ but carriers may be required to include the fee in their state tariffs, which are reviewed by the state commission to ensure the fees are just and reasonable. ${ }^{285}$ These tariffs may include general rules, like a commitment that the carrier will install up to two new poles without charging a CIAC, or state law may limit CIAC practices. ${ }^{286} \mathrm{New}$ Jersey, for example, prohibits CIACs where a line extension would be profitable even without a CIAC. ${ }^{287}$ Again, this paper is not specifically endorsing any one approach, but the example of line extension rules shows how policymakers could examine the various approach different states have taken to implement COLR duties when crafting rules for broadband carriers.

Of course, if policymakers choose to pursue COLR rules to achieve universal voice and broadband service, they will need to confront many more issues and answer many more questions about what a COLR obligation for broadband could look like, who it would apply to, and how transitions to the new regime would operate. ${ }^{288}$ For example, how would COLR duties differ from the duties of an ETC receiving financial support? How should the COLR duties be as-

\footnotetext{
280 See Fed. CommC'Ns Comm'N, supra note 102, at 17; see also Fed. CommC'NS Comm'n, Indus. Analysis and TeCh. Division: Wireline Competition Bureau, InTERNET ACCESS SERVICES: StATUS AS OF DEC. 31, 201266 (2013).

281 See FED. COMMC'NS COMM'N, supra note 129, at 66 (Chart 17).

282 Id. at 70 (Chart 21).

283 See BluHM \& BeRnT, PhD, supra note 239, at 8.

284 See id.

285 See, e.g., 52 PA. CODE $§ 63.20$ (1969); see, e.g., N.J. STAT. AnN. § 48:2-27 (2015).

286 BLUHM \& BERNT, PHD, supra note 239, at 8-9.

$287 \S 48: 2-27$.

288 See Bernt, supra note 274, at 133 (listing examples of questions that must be confronted).
} 
signed to carriers? When should they arise or expire for each carrier, and when can an unsuccessful COLR exit the market?

\section{THE UNIVERSAL SERVICE FUND}

Another approach to achieving universal service - which can be used in conjunction with other universal service policies and projects - is to establish funding mechanisms to defray the costs of building new lines in low-income or high-cost areas. ${ }^{289}$ In recognition that basic communications service (traditionally voice) is "crucial to full participation in our society and economy which are increasingly dependent upon the rapid exchange of information, ${ }^{290}$ the FCC for some time has collected funds from telecommunication providers and others to sponsor substantial programs through the Universal Service Fund. ${ }^{291}$ Currently, the Universal Service Fund includes the Connect America Fund for high-cost rural areas, ${ }^{292}$ the Lifeline program and Link Up America program for low-income consumers, ${ }^{293}$ the Schools and Libraries program, ${ }^{294}$ and the Rural Health Care program. ${ }^{295}$

In recent years the FCC has updated its USF programs to increasingly support broadband deployment and adoption. ${ }^{296}$ Spurred in part by recommendations in the National Broadband Plan, the high cost fund, rural health care, and E-rate programs have all been adjusted to incentivize and enable broadband deployment to rural areas and anchor institutions like hospitals, schools, and libraries. ${ }^{297}$ In 2013, the FCC made up to $\$ 400$ million available annually to aid broadband deployment to support telemedicine initiatives, ${ }^{298}$ and in 2011 the FCC updated its Connect America Fund and intercarrier compensation regime to support networks that offer both basic voice and broadband service. ${ }^{299}$ By tying broadband service to voice service for funding purposes, the FCC has

\footnotetext{
289 See Universal Service, supra note 16.

290 MTS and WATS Market Structure, and Amendment of Parts $67 \& 69$ of the Commission's Rules and Establishment of a Joint Board, Report and Order, 50 Fed. Reg. 939 (Jan. 8, 1985).

291 Universal Service, supra note 16.

292 See Connect America Fund, FCC, http://www.fcc.gov/encyclopedia/connectingamerica (last visited Mar. 13, 2015).

293 See Lifeline Program for Low-Income Consumers, supra note 100.

294 Universal Service, supra note 16.

295 Id.

$296 I d$.

297 Id.

298 FCC Chairman Genachowski Announces Up to $\$ 400$ Million Healthcare Connect Fund to Create \& Expand Telemedicine Networks, Increase Access to Medical Specialists, FCC (Jan. 7, 2013), http://www.fcc.gov/document/fcc-chairman-announces-400-millionhealthcare-connect-fund.

299 USF/ICC Transformation Order, 26 FCC Rcd 17663 para. 648.
} 
thus far passed judicial scrutiny, ${ }^{300}$ but it is not clear what the future of the high cost programs will be as usage shifts more to broadband and potentially away from traditional voice service. The FCC's recent decision to reclassify broadband Internet access service as a Title II telecommunications service strengthens the Commission's authority under $\S 254$ to modernize USF programs by applying them to broadband, even sometimes as a standalone product, but the actual rules implementing those changes have not been created yet. ${ }^{301}$

In 2014, the Commission set new broadband connectivity targets for schools and libraries in addition to establishing new target expenditures for WiFi support, and later increased the E-rate cap from $\$ 2.25$ billion to $\$ 3.9$ billion to better meet the program's connectivity goals. ${ }^{302}$ However, Commissioner Clyburn and Commissioner Rosenworcel have both pointed out that a lack of broadband connectivity at home will result in a persistent "homework gap" that will leave some students at a strong disadvantage. ${ }^{303}$

This has made the topic of reforming subsidies for low-income households to gain greater traction among policymakers recently. ${ }^{304} \mathrm{FCC}$ Commissioner Mignon Clyburn has recommended reforms like including standalone broadband as a supported service for Lifeline customers, in addition to establishing minimum service standards for Lifeline providers, removing carriers' responsibility to determine customers' eligibility, implementing a streamlined approval process, instituting coordinated enrollment with other government benefits programs, and creating public-private partnerships to coordinate outreach efforts. ${ }^{305}$ Shortly afterward, Commissioner Michael O'Rielly set forth his own principles for Lifeline reform, generally designed to limit the size of the program and implement more safeguards against abuse. ${ }^{306}$

Outside of the FCC, other actors have been debating and taking action on reforming universal service mechanisms. ${ }^{307}$ The California Public Utilities Com-

\footnotetext{
300 See generally Petitions for Review of Orders of the Federal Communications Commission, In re: FCC 11-161, 753 F.3d 1015 (10th Cir. 2014) (No. 11-9900).

301 See Net Neutrality Order GN Docket No. 14-28, paras. 59, 486.

302 In the Matter of Modernizing the E-rate Program for Schools and Libraries, Connect America Fund, Second Report and Order and Order on Reconsideration WC Docket No. 13184, WC Docket No. 10-90, 29 FCC Rcd 15538 paras. 78, 81 (Dec. 11, 2014).

303 See Mignon Clyburn, Commissioner, Fed. Commc'ns Comm'n, Reforming Lifeline for the Broadband Era (Nov. 12, 2014), available at http://www.fcc.gov/document/commissioner-clyburn-remarks-american-enterprise-institute; see also Jessica Rosenworcel, Commissioner, Fed. Election Comm'n, Remarks to the Texas Computer Association (Feb. 4, 2015), available at http://www.fcc.gov/document/rosenworcel-remarks-texas-computer-education-association.

304 Clyburn, supra note 303.

305 Id.

306 Michael O'Rielly, Sound Principles for Lifeline Reform, FCC Blog (Feb. 13, 2015, 3:51 PM), http://www.fcc.gov/blog/sound-principles-lifeline-reform.

307 See NTCA- The RuRAL BROADBAND AsSOCIATION COMMENTS IN RESPONSE to U.S.
} 
mission has voted unanimously to include smartphone service with voice, text, and data capabilities in its state Lifeline program. ${ }^{308}$ In the private sector, the Internet Innovation Alliance- a coalition whose members include AT\&T, the American Conservative Union, and Alcatel-Lucent-recently called for updating the federal Lifeline program by bringing a new focus to support for broadband, distributing benefits through a voucher system, and determining eligibility through the government instead of providers. ${ }^{309}$

A shift in technologies, and how many people are using those technologies, could also have tremendous impact on how payments travel into and out from universal service programs. ${ }^{310}$ For example, as fewer people shift from services that pay into the USF and over to newer technologies that do not, the base of contributions has been shrinking while the need for greater deployment and adoption has not. ${ }^{311}$ On this point the FCC recently asked the Federal-State Joint Board on Universal Service to make recommendations to modify the universal service contribution methodology. ${ }^{312}$

It will be important to continue to evaluate which communities are being reached by universal service programs throughout technology transitions. Anchor institutions, rural areas, tribal lands, and urban and suburban areas all rely in some way on the existing funding mechanisms to remain connected to the up-to-date basic technologies. ${ }^{313}$ Leaving these communities behind, intention-

House of Representatives Energy and Commerce Committee White PAPer 5: UniverSal Service Policy and the role of the Federal Communications Commission 2, 4-5 (2014), available at https://prodnet.www.neca.org/publicationsdocs/wwpdf/91914ntca.pdf; see also Marc Lifsher, PUC Makes Cellphones Eligible for Low-Cost LifeLine Program, L.A. TIMES (Jan. 16, 2014), http://www.latimes.com/business/la-fi-phone-regulations20140117-story.html.

308 Lifsher, supra note 307.

309 Community, INTERNET Allavation http://internetinnovation.org/community/members/ (last visited Feb. 24, 2015); INTERNET InNovation Alliance, Bringing THE FCC's Lifeline Program InTO THE $21^{\text {sT }}$ CENTURY 4, (2014) available

http://internetinnovation.org/images/misc_content/Lifeline_White_Paper_FINAL.pdf.

310 See FED. COMMC'NS COMM'N, supra note 126, at $\overline{135}$, 142.; see CHARLES AQUARD, Response to the House Committee on Energy and Commerce Fifth White Paper on, UnIVERSAL SERVICE POLICY 2 (2014).

311 Hearing Before the Committee on Commerce, Science, and Transportation United States Senate, 109th Cong. 11 (2006) (prepared statement of Glen Post, Chairman/Chief Executive Officer, Centurytel, Inc.).

312 In the Matter of Federal State Joint Board on Universal Service, Universal Service Contribution Methodology, A National Broadband Plan for Our Future, Order, WC Docket No. 96-45, WC Docket No. 06-122, GN Docket No. 09-51, 29 FCC Rcd 9784 (Aug. 6, 2014).

313 See Alaska Commc'n Sys., Re: Committee on Energy \& Commerce White PaPer, Universal Service Policy and the Role of the Federal Communications ComMISSION 1-2 (2014); see, e.g., Modernization of the Schools and Libraries "E-rate" Program and Connect America Fund, 80 Fed. Reg. 23, 5968 (Feb. 4, 2015); see generally NAT'L 
ally or not, in the transition would risk driving a wedge even further in the digital divide.

\section{NONDISCRIMINATION POLICIES}

As the Commission has explained, ${ }^{314}$ net neutrality and other open Internet rules can themselves encourage more broadband deployment. ${ }^{315}$ In the "virtuous cycle of innovation," new network functions lead to greater demand for improved broadband service, which leads to broadband infrastructure investment, which then leads to innovators developing more network functions. ${ }^{316}$ However, if broadband providers could leverage their control over the last-mile infrastructure to prioritize some companies' traffic over others, broadband providers' incentive to invest in their infrastructure and market entrants' incentive to bring new data-intensive applications to market would be seriously threatened. ${ }^{317}$

Similarly, policymakers understanding the use of data capacity thresholds ("data caps") is crucial to ensuring capacity limits do not create a disincentive to invest in networks. ${ }^{318}$ If providers can place artificial limits on customers' capacity demands - and indeed profit from those limits - providers will have precious little incentive to invest in more robust networks that have even less

Cong. of Am. Indians, Re: Committee on Energy \& Commerce White PaPer, Universal Service Policy and the Role of the Federal Communications Commission 1 (2014) (providing an example of how tribal lands are becoming increasingly involved with in and are starting to take steps to rely on the existing broadband universal services).

314 See In the Matter of Inquiry Concerning the Deployment of Advanced Telecommunications Capability to All Americans in a Reasonable and Timely Fashion, and Possible Steps to Accelerate Such Deployment Pursuant to Section 706 of the Telecommunications Act of 1996, as Amended by the Broadband Data Improvement Act, 2015 Broadband Progress Report and Notice of Inquiry on Immediate Action to Accelerate Deployment, GN Docket No. 14-126, para. 151 (Jan. 29, 2015).

315 See, e.g., In re Deployment of Advanced Telecommunications Capability to All Americans in a Reasonable and Timely Fashion, and Possible Steps to Accelerate Such Deployment Pursuant to Section 706 of the Telecommunications Act of 1996, as Amended by the Broadband Data Improvement Act, Comments of Netflix, Inc., GN Docket No. 14126, at 13, 14-15 (Sept. 4, 2014) (discussing the "virtuous circle of innovation" that open Internet facilitates).

316 See id. at 13-14.

317 See In re Inquiry Concerning the Deployment of Advanced Telecommunications Capability to All Americans in a Reasonable and Timely Fashion, and Possible Steps to Accelerate Such Deployment Pursuant to Section 706 of the Telecommunications Act of 1996, as Amended by the Broadband Data Improvement Act, Comments of Public Knowledge, GN Docket No. 14-126, at 7-8, 9, 11 (Sept. 4, 2014) ("A company that controls broadband access and profits from charging consumers for video, voice, and data separately has an economic incentive to leverage that broadband access control to protect its other revenue streams.").

318 See id. at 4,6 . 
technical need for data caps. ${ }^{319}$ To put another way, when broadband providers can very profitably monetize artificial scarcity, they have little reason to create actual abundance. ${ }^{320}$

In this sense, "open-Internet-as-universal-service" policy may sometimes fit better in the context of improving existing infrastructure (particularly broadband infrastructure that no longer qualifies as broadband due to evolving technological standards), as opposed to encouraging greenfield deployment. ${ }^{321}$ However, ensuring that the broadband service being provided continues to develop in line with the evolving standards for "basic service" makes this a potentially important tool for the FCC in efforts to ensure high-quality networks proliferate. ${ }^{322}$

Additionally, interconnection policies, although somewhat different than the traditional net neutrality concerns of discrimination in the last mile of the network, can have significant impact on the viability of new networks. ${ }^{323}$ Any network, whether offering basic voice or Internet access service, must directly or indirectly physically connect with other networks to offer its customers phone service or Internet access. ${ }^{324}$ Ensuring efficient interconnection between networks encourages network deployment by getting those networks online, and is therefore a significant tool for achieving universal service. ${ }^{325}$

Now that the FCC has reclassified broadband Internet access service as a telecommunications service and established strong open Internet rules, the stage is well set to see how those rules incentivize carriers to invest in their networks, rather than monetizing artificial scarcity in network capacity. ${ }^{326}$

\footnotetext{
319 Id. at $9,11$.

$320 \mathrm{Id}$. at 11 .

321 See Comments of Netflix, Inc., GN Docket No. 14-126, at 13-14; Cory Janssen, Greenfield Deployment, TECHOPEDIA, http://www.techopedia.com/definition/5063/greenfield-deployment (last visited Feb. 24, 2015) (explaining that, converse to Net Neutrality, greenfield deployment builds the network from scratch, having no impact on the improvement of existing networks).

322 See N.Y. Pub. Serv. Comm'N, 05-C-0616, Proceeding on Motion of the CommisSION tO EXAMINE IsSUES RELATED TO THE TRANSITION TO INTERMODAL COMPETITION IN THE Provision of Telecommunications Services, Comments of the Communications WORKERS OF AMERICA, AFL-CIO 14-16, 25 (Aug. 15, 2005).

323 Bruce Edgerton, Interconnection- New Policies Promote Competition, ConnectWORLD (1997), http://www.connect-world.com/index.php/magazines/latinamerica/item/1959-interconnection-\%E2\%80\%93-new-policies-promote-competition.

324 See Telecommunications Regulation Handbook: Module 3 Interconnection, 3-2 (Hank Intven ed., \& McCarthy Tetrault 2000), available at http://www.itu.int/ITU$\mathrm{D} /$ treg/Documentation/Infodev_handbook/3_Interconnection.pdf (defining this process, known as "interconnection").

325 See Letter from Brad E. Mutschelknaus \& Edward A. Yorkgitis, Jr., Counsel for Eschelon Telecom et al., to Marlene H. Dortch, Secretary, Fed. Commc'ns Comm'n 1-2 (June 6, 2005), available at http://apps.fcc.gov/ecfs/document/view?id=60001010005.

326 See Net Neutrality Order, GN Docket No. 14-28, para. 151.
} 


\section{VOLUNTARY APPROACHES}

Whether independent or combined with the types of policies described above, voluntary efforts to increase build-out, especially for broadband, can have significant impacts within their geographic purviews. ${ }^{327}$ Whether launched by local governments or private companies, voluntary efforts to increase broadband infrastructure or adoption may not have the same reach as a national or state-level universal service regime, but can play an important role in increasing broadband access over the long term. ${ }^{328}$

Municipal broadband efforts have become increasingly popular as municipalities that either have little competition in the broadband marketplace or no broadband infrastructure at all decide to take matters in their own hands and gain local control over the next generation of their communities' infrastructure. ${ }^{329}$ Local broadband planning allows network planners to pay particular attention to improving access to the community's anchor institutions, and can be constructed for less cost if coordinated with other infrastructure projects like repairs to roads or water or electricity infrastructure. ${ }^{330}$

Municipal broadband projects have launched under a number of different financing options and business models. ${ }^{331}$ Not every municipal broadband project has been successful, but enough success stories have appeared that the efforts have drawn the attention of national policymakers at the FCC, which is currently considering whether to preempt state laws that restrict community broadband efforts. ${ }^{332}$ In addition to President Obama recently voicing strong

327 See Connect America Fund, supra note, 292; see, e.g., Michael J. Copps, Bringing Broadband to Rural America: Report on Rural Broadband Strategy 51, 53-54 paras. 118, 120 (2009); see also Letter from Thomas A. Schatz, President, Council for Citizens Against Government Waste, to Hon. Greg Walden, Chairman, Subcommittee on Communications and Technology, Committee on Energy and Commerce, U.S. House of Representatives \& Hon. Anna Eshoo, Ranking Member, Subcommittee on Communications and Technology, Committee on Energy and Commerce, U.S. House of Representatives 4 (Sept. 17, 2014), available

http://energycommerce.house.gov/sites/republicans.energycommerce.house.gov/files/analys is/CommActUpdate/WP5_Responses_1-18.pdf (describing how private entities have begun to fund network improvement projects).

328 See Letter from Thomas A. Schatz, supra note 327, at 3, 5, 8 (describing how state and federal government programs have an abundance of resources that are specifically allocated to network build out).

329 Community Connectivity Toolkit, COMMUNity BroAdBAND NeTworks, http://muninetworks.org/content/community-connectivity-toolkit (last visited Feb. 25, 2015).

330 See Nw. Colo. Council of Gov'ts, Regional Broadband Strategic PLAN 28, 130, 134 (2013), available at http://co.grand.co.us/DocumentCenter/View/2100.

331 See How Municipal Networks are Financed, InST. FOR LOCAL SELF-Reliance, http://www.ilsr.org/wp-content/uploads/2014/01/financing-munis-fact-sheet.pdf (last visited Mar. 13, 2015).

332 See, e.g., Opelika Speaks From Experience: Support Local Authority!, CommUnITY 
support for municipal broadband efforts, ${ }^{333}$ the Department of Commerce's National Telecommunication and Information Administration and the Department of Agriculture have announced new support, tactical assistance, and loan opportunities for new networks. ${ }^{334}$

Finally, less traditional efforts like voluntary commitments by carriers to provide reasonably priced basic broadband service have resulted in more access for at least some portion of underserved populations. ${ }^{335}$ For example, Comcast's Internet Essentials program offers basic broadband service for a base price of $\$ 9.95$ per month. ${ }^{336}$ Eligibility for the program is quite limited, as the program is only offered to participants: (1) within Comcast's existing footprint; (2) having at least one child eligible to participate in the National School Lunch Program; and (3) who are not recent Comcast customers or have outstanding debt due to Comcast. ${ }^{337}$ Even within that portion of the population, adoption is a small fraction of the eligible population-for example, one recent estimate of Comcast's Internet Essentials program in California put adoption rates at $11 \%$ of eligible households. ${ }^{338}$ Even though the service has slowly reached only some of the eligible subscribers who would otherwise not have broadband in their home, the service is worth examining for ways to improve access to households that currently do not have broadband service. ${ }^{339}$

This type of program may not be workable with its current limitations to reach true universality on its own, but it could play at least some small part in getting more people online while policymakers pursue other approaches to encourage build-out and affordability. However, in the context of its proposed merger with Time Warner Cable, Comcast has bristled against proposals to strengthen the Internet Essentials service and improve adoption among eligible

BROADBAND NETWORKS (Feb. 25, 2015), http://www.muninetworks.org/content/opelikaspeaks-experience-support-local-authority.

333 Office of Press Sec'y, supra note 2.

334 Lawrence Strickling, NTIA Announces BroadbandUSA Effort to Assist Communities with Broadband Plans, BroAdBAndUSA (Jan. 14, 2015), http://www2.ntia.doc.gov/ntia_announces_broadbandusa_effort; USDA Announces Funding for Rural Broadband and Telecommunications Infrastructure, U.S. DEP'T OF AGRIC. (Oct. 22, 2014), http://www.usda.gov/wps/portal/usda/usdahome?contentidonly=true\&contentid=2014/10/02 34.xml.

335 Matt Larsen, America's Broadband Heroes: Fixed Wireless Broadband 2 (2011), available at http://www.wirelesscowboys.com/wpcontent/uploads/2011/10/americas-broadband-heroes-fixed-wireless-2011.pdf.

336 Internet Essentials Support, COMCAST, http://learning.internetessentials.com/internetessentials-support (last visited Feb. 25, 2015).

337 Id.

338 See In re Application of Comcast Corporation and Time Warner Cable Inc. and Spinco to Assign and Transfer Control of FCC Licenses and Other Authorizations, Comments of the California Emerging Technology Fund, MB Docket No. 14-57, at 4 (Aug. 25, 2014).

339 See id. at 3. 
households.$^{340}$ If Comcast and other carriers decline to invest in improving the performance and efficacy of voluntary measures like Internet Essentials, it may not turn out to be a viable model to meaningfully improve adoption. ${ }^{341}$

\section{CONCLUSION}

As the network transitions in several different ways, policymakers have the challenge of seizing the opportunities presented by new technologies and preventing potential harms from network changes. We have already seen evidence that not every technological change will automatically be a step forward for everyone ${ }^{342}$ - or even for most-so communications policy must continue to pursue universal, reliable, and affordable communications service. The technologies will inevitably change, and the services at issue may even upgrade as well, but the basic social needs remain the same. If policymakers examine and evaluate the tools the U.S. has used in the past to achieve universal service, they may find lessons and tools that can be useful in crafting policies to accomplish universal broadband service in the years to come.

\footnotetext{
340 Jon Brodkin, Comcast Gets a Merger Approval, But Objects to New Low-Income Requirements, ARs TECHNICA (Feb. 14, 2015), http://arstechnica.com/business/2015/02/comcast-gets-a-merger-approval-but-objects-tonew-low-income-requirements/.

341 See Comments of the California Emerging Technology Fund, MB Docket No. 14-57, at 24; see Kate Cox, Two Big Reasons The New Broadband Standard Is Bad News For The Comcast Merger, Consumerist (Jan. 29, 2015), http://consumerist.com/2015/01/29/twobig-reasons-the-new-broadband-standard-is-bad-news-for-the-comcast-merger/ (explaining that because Comcast's program narrows the digital divide by providing low income families with low cost Internet access, there would be more people without Internet access without investment and support from Comcast to implement Internet Essentials).

342 KATHERINE BATES ET AL., ICF INT'L, Closing the Digital Divide: Promoting Broadband Adoption Among Underserved Populations 1, 2,13 (2012).
} 